\title{
Brazilian Protocol for Sexually Transmitted Infections 2020: human T-cell lymphotropic virus (HTLV) infection
}

\author{
Carolina Rosadas ${ }^{[1]}$, Carlos Brites ${ }^{[2]}$, Denise Arakaki-Sanchez ${ }^{[3]}$, \\ Jorge Casseb ${ }^{[4]}$ and Ricardo Ishak ${ }^{[5]}$
}

\author{
[1]. Imperial College London, Department of Infectious Disease, London, United Kingdom. \\ [2]. Universidade Federal da Bahia, Faculdade de Medicina, Salvador, BA, Brasil. \\ [3]. Ministério da Saúde, Secretaria de Vigilância em Saúde, Brasília, DF, Brasil. \\ [4]. Universidade de São Paulo, Faculdade de Medicina, São Paulo, SP, Brasil. \\ [5]. Universidade Federal do Pará, Instituto de Ciências Biológicas, Belém, PA, Brasil.
}

\begin{abstract}
This article addresses the Human T-lymphotropic virus (HTLV). This subject comprises the Clinical Protocol and Therapeutic Guidelines for Comprehensive Care for People with Sexually Transmitted Infections, published by the Brazilian Ministry of Health. HTLV-1/2 infection is a public health problem globally, and Brazil has the largest number of individuals living with the virus. HTLV-1 causes several clinical manifestations of neoplasm (adult T-cell leukemia/lymphoma) and inflammatory nature, such as HTLV-1-associated myelopathy and other manifestations such as uveitis, arthritis, and infective dermatitis. These pathologies have high morbidity and mortality and negatively impact the quality of life of infected individuals. This review includes relevant information for health authorities professionals regarding viral transmission, diagnosis, treatment, and monitoring of individuals living with HTLV-1 and 2 in Brazil.
\end{abstract}

Keywords: Human T-Cell lymphotropic virus 1. Sexually transmitted diseases. Diagnosis. Signs and symptoms. Disease prevention.

Highlighted excerpt: HTLV-1/2 transmission can occur through blood transfusion and derivatives, injectable drug use, organ transplantation, unprotected sexual intercourse, and vertical transmission.

\section{FOREWORD}

This article addresses Human T-lymphotropic virus (HTLV) infection. This subject comprises the Clinical Protocol and Therapeutic Guidelines (PCDT) for Comprehensive Care for People with Sexually Transmitted Infections (STI), published by the Health Surveillance Department of the Brazilian Ministry of Health. To elaborate the PCDT, selection and analysis of the evidence available in the literature were performed, and a panel of specialists discussed it. The document was approved by the National Committee for the Incorporation of Technologies in the Brazilian National Health System (Conitec) ${ }^{1}$ and updated by the team of specialists in STI in $2020^{2}$.

\footnotetext{
Corresponding author: Ricardo Ishak.

e-mail: rishak@ufpa.br

(iD) https://orcid.org/0000-0002-4741-6201

Received 01 February 2021

Accepted 10 March 2021
}

\section{EPIDEMIOLOGICAL ASPECTS}

HTLV-1 was described in patients with adult T-cell leukemia/ lymphoma and, like HTLV-2 ${ }^{3-6}$, classified in the Retroviridae family, genus Deltaretrovirus ${ }^{7}$. There are six molecular subtypes (a, b, c, d, e, f) of HTLV-1 $1^{8-10}$ and four (a, b, c, d) of HTLV-2 $2^{11-14}$; and two other types, HTLV-3 and HTLV-4, which have been described in isolated areas of forests in Cameroon, a country in the western region of Central Africa, and not yet associated with clinical manifestations ${ }^{15-17}$.

HTLV-1/2 infection results from the transmission of infected lymphocytes, present in body fluids (blood, semen, vaginal secretion, and mother's milk), by transfusion of blood and derivatives, intravenous drug use, organ transplantation, unprotected sexual intercourse, and vertical transmission. Vertical transmission can occur by the placental route, during birth, and mainly by breastfeeding ${ }^{18-25}$. HTLV-1 proviral load and exposure time are related to the increased risk of transmission, especially during sexual intercourse or breastfeeding ${ }^{26}$. The risk associated with the transfusion of blood and its derivatives was significantly reduced, with the introduction of systematic screening of blood and organs and blood components' leukoreduction ${ }^{27,28}$. 
Sexual contact is an important route of HTLV-1 and HTLV-2 dissemination in urban, rural, and indigenous areas ${ }^{12,29,30}$. In urban areas, infection is most common among women ${ }^{31-33}$. However, among indigenous communities, the transmission effectiveness shows no difference between the sexes ${ }^{12,29,34}$. Sexual transmission is associated with unprotected sex practices, sexual partnership with intravenous drug users, and the presence of other $\mathrm{STI}^{35-37}$.

HTLV-1 and HTLV-2 are distributed worldwide ${ }^{18}$. Brazil has variable frequencies, ranging from 0.01 to $1.35 \%$ in the general population $28,38,39$, according to the geographical area and behavioral risk factors ${ }^{12,18,40,41}$. Groups with higher vulnerability to infection by both viruses include (i) intravenous drug users, (ii) sex workers, (iii) men who have sex with men, (iv) individuals submitted to blood transfusion before 1993, and (v) sexual partners of individuals with known HTLV infection. The decrease in HTLV-1 prevalence among blood donors throughout the years ${ }^{28,38}$ is a privileged situation in Brazil, promoted since $1993^{42}$ with the mandatory screening regulation of blood and its products.

The seroepidemiological studies for HTLV-1/2 are based on the detection of specific antibodies. It is important to emphasize that few population studies were conducted adequately. Therefore, a significant part of the epidemiological information about HTLV-1/2 derived from old studies, which often do not sufficiently define incidence and prevalence rates, shows conflicting results and does not allow the definition of precise prevention and control measures ${ }^{18,39}$.

HTLV-2, considered an ancestral infection, is apparently well adapted to humans, with rare clinical manifestations ${ }^{5,43-48}$. HTLV-2 is usually used as a marker of human migrations after the departure from the African continent ${ }^{49,50}$.

\section{CLINICAL ASPECTS}

Retroviruses integrate with the nucleic acid in the infected cell and establish a viral persistence, leading to the virus maintenance and the different outcomes of the infection. HTLV-1 is associated with an aggressive malignant disease, adult T-cell leukemia/ lymphoma (ATL) ${ }^{51,52}$, and the neurodegenerative disease HTLV-1 associated myelopathy (HAM) $)^{53-57}$.

HTLV-1 infection shows a great variety of interactions with the human host and important clinical manifestations have been recognized in the eye $\mathrm{e}^{58-61}$, skin $^{61,62}$, lung ${ }^{61,63-65}$, joints ${ }^{66-68}$, thyroid ${ }^{69,70}$, heart $^{61,71,72}$, intestines $^{61,73}$ and bladder ${ }^{61,74,75}$, among others. The broad spectrum of diseases reveals the infection's clinical complexity, which requires multidisciplinary attention for the infected patients' care. Although the clinical outcome of the HTLV-1 infections is considered low (5\%), the number of clinical cases associated with HTLV-1 infection can reach a higher level and still needs to be better defined ${ }^{55}$. Intermediate clinical manifestations can be frequent before HAM occurs ${ }^{76,77}$. The proviral load in HTLV-1 infection is important in disease progression ${ }^{78,79}$, and is usually lower in asymptomatic individuals compared with those who present HTLV-1 associated diseases.

\section{HTLV-1 ASSOCIATED MYELOPATHY}

HAM occurs in about $4 \%$ of HTLV carriers, although clinical manifestations may affect more than $10 \%$ of them ${ }^{77}$. HAM manifests predominantly in the fourth and fifth decades of life, being uncommon before 20 or after 70 years of age. Generally, it starts insidiously and progresses slowly, especially among women: HAM cases in women are two to three times higher than that observed among men. Gait disturbances are a consequence to the gradual decrease in muscle strength and spasticity of the lower limbs ${ }^{80}$, leading to the need, over time, for walking aids (with the support of canes and walkers) and may evolve into the use of a wheelchair. The time of evolution varies, from months to decades. The symptoms of vesicointestinal and sexual dysfunction can be the initial complaints of the affected individual. Generally, HAM is characterized by urinary urge incontinence, intestinal constipation, and erectile dysfunction in the male population. The neurological clinical picture may be associated with multisystemic processes such as dermatitis, uveitis, pneumonia, besides cognitive alterations ${ }^{81,82}$. The diagnosis of HAM is rather critical since its early treatment may lead to a more effective therapeutic response ${ }^{83}$ and better prognosis when instituted up to five years after the first symptoms.

Proviral load levels correlate with the progression of the disease, especially with muscle weakness. Although the magnitude of the proviral load in peripheral blood is associated with HAM, it is not the sole diagnostic or prognostic factor of the pathology ${ }^{84}$. Proviral load in cerebrospinal fluid is important to define the progression of HAM since HTLV-1 infected cells in the central nervous system accelerate the local inflammatory process ${ }^{26,85-87}$. However, other prognostic value markers should be evaluated to identify people at higher risk of illness ${ }^{88-90}$.

\section{ADULT T-CELL LEUKEMIA/LYMPHOMA}

The neoplasm of peripheral T-cells caused by HTLV-1 presents itself with leukocytosis, characterized by the presence of abnormal lymphocytes (flower cells) and, clinically, by lymphadenopathies, skin lesions, dysfunction of multiple organs resulting from the invasion of the neoplastic cells, in addition to the presence of opportunistic infections. Elevated levels of the enzyme lactate dehydrogenase and hypercalcemia are characteristic. In Japan, there are over one million carriers and the incidence of ATL varies from 0.6 to 0.7 per 1000 persons $/$ year $^{91}$. The risk of illness is higher in men, and symptoms begin 20 to 30 years after infection ${ }^{92}$. Rarely, ATL occurs before 30 years of age; however, its frequency tends to increase to reach those with 70 years of age. In Japan, where the probability of developing ATL is 5\%, risk factors are: (i) maternal transmission, (ii) older age, (iii) increased proviral load in peripheral blood, (iv) family history of ATL, and (v) prior positive testing for anti-HTLV- $1^{93,94}$. ATL is rare in other countries, not reaching $2 \%$ of cases $^{95}$, despite evidence of lack of diagnosis ${ }^{96,97}$.

Four clinical forms of ATL are recognized ${ }^{98}$, which take into account the presence and severity of the leukemic manifestations, in addition to altered laboratory tests, such as increased lactate dehydrogenase and hypercalcemia. This classification is described in Figure 1, and the factors that predict worse prognosis, including those mentioned above, are found in Figure $2^{51,98-101}$.

\section{DERMATOLOGICAL ALTERATIONS IN INDIVIDUALS WITH HTLV}

In addition to the clinical manifestations classically associated with HTLV-1 in the skin, such as infective dermatitis and the 


\begin{tabular}{|c|c|c|c|c|}
\hline Classification and frequency & Clinical manifestations & Median survival & Diagnosis & Other findings \\
\hline Acute (42 to $47 \%$ ) & $\begin{array}{l}\text { Leukemic stage, aggressive } \\
\text { form, leukocytosis, generalized } \\
\text { lymphadenomegaly. } \\
\text { Skin and bone lesions, } \\
\text { pulmonary infiltrates, central } \\
\text { nervous system involvement } \\
\text { (10\% of cases). }\end{array}$ & Six months & $\begin{array}{c}\text { Histological } \\
\text { confirmation required } \\
\text { if }<5 \% \text { abnormal } \\
\text { lymphocytes }\end{array}$ & $\begin{array}{c}\text { Hypercalcemia, } \\
\text { fractures, bone pain, skin } \\
\text { exanthem, the elevation } \\
\text { of alkaline phosphatase } \\
\text { without apparent cause }\end{array}$ \\
\hline Lymphomatous (19\%) & $\begin{array}{c}\text { Fast course, lymphadenopathy, } \\
\text { hepatosplenomegaly, skin } \\
\text { lesions such as erythematous } \\
\text { exanthem, papules, and } \\
\text { nodules. }\end{array}$ & Ten months & $\begin{array}{l}\text { Histological } \\
\text { confirmation required } \\
\text { if }<5 \% \text { abnormal } \\
\text { lymphocytes }\end{array}$ & $\begin{array}{l}\text { Less frequent } \\
\text { hypercalcemia, rare } \\
\text { circulating tumor cells }\end{array}$ \\
\hline $\begin{array}{l}\text { Chronic (19\%): favorable } \\
\text { (indolent) }\end{array}$ & $\begin{array}{c}\text { Slow course, skin exfoliative } \\
\text { exanthem, lymphocitosis }\end{array}$ & Four years & $\begin{array}{c}\text { Histological } \\
\text { confirmation required } \\
\text { if }<5 \% \text { abnormal } \\
\text { lymphocytes, absolute } \\
\text { lymphocytosis by } T \\
\text { lymphocytes. }\end{array}$ & $\begin{array}{c}\text { Flower cells can be } \\
\text { seen, increased lactate } \\
\text { dehydrogenase, absent } \\
\text { hypercalcemia }\end{array}$ \\
\hline Unfavorable & Fast course & 15 months & $\begin{array}{c}\text { Histological } \\
\text { confirmation required } \\
\text { if }<5 \% \text { abnormal } \\
\text { lymphocytes }\end{array}$ & $\begin{array}{l}\text { Increased urea and } \\
\text { lactate dehydrogenase, } \\
\text { decreased albumin, } \\
\text { flower cells can be seen }\end{array}$ \\
\hline Smoldering (6\%) & $\begin{array}{l}\text { Slow course, normal cell count } \\
\text { skin and lung lesions }\end{array}$ & Four years & $\begin{array}{c}\text { Histological } \\
\text { confirmation required } \\
\text { if }<5 \% \text { abnormal } \\
\text { lymphocytes, normal } \\
\text { leucometry }\end{array}$ & $\begin{array}{l}\text { Flower cells can be } \\
\text { seen }(5 \% \text { or more) in } \\
\text { peripheral blood, without } \\
\text { hypercalcemia }\end{array}$ \\
\hline
\end{tabular}

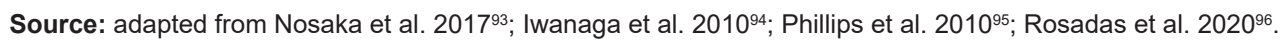

Note: a) Need for intrathecal chemotherapy.

FIGURE 1: Classification and characteristics of adult T-cell leukemia/lymphoma.

Poor status performance

Increased lactate dehydrogenase

Presence of 4 or more skin lesions

Hypercalcemia

Age over 40 years

Thrombocytopenia

Eosinophilia

Bone marrow involvement

Interleukin 5 serum level increase

C-C chemokine receptor type 4 (CCR4) expression

Lung resistance-related protein gene expression

Protein 53 (p53) mutation

Protein $16(\mathrm{p} 16)$ deletion

Soluble interleukin-2 receptor dosage, especially after allogeneic hematopoietic progenitor cell transplantation

The presence of positive T-CD $30^{+}$lymphocyte (cluster designation) expression in tumour cells (with polylobed characteristics and chromosomal aberrations), considered a tumorigenic marker of the disease

Source: adapted from Iwanaga et al. $2010^{94}$.

FIGURE 2: Adult T-cell leukemia/lymphoma worst prognosis predictors. 
cutaneous manifestations of ATL, other dermatological affections attributed to the infection have been described as serious forms of scabies (especially in HIV-1 coinfected individuals) ${ }^{102}$, ichthyoses, seborrheic dermatitis, and dermatophytoses ${ }^{103}$.

At first, infective dermatitis was described in Jamaican children infected by HTLV-1 ${ }^{104}$, mainly when vertical transmission occurs, although the disease can also affect adolescents and adults ${ }^{105}$. Infective dermatitis is characterized by erythematous-desquamative lesions, which generally involve the scalp, retro auricular regions, neck, face, armpits, and inguinal region. Typically, it is associated with infection by Gram-positive bacteria such as Streptococcus beta-hemoliticus and Staphylococcus aureus. According to a case series study, almost half of the individuals who had long-term follow-up were also diagnosed with $\mathrm{HAM}^{106}$. The differential diagnosis includes other causes of chronic eczemas, such as atopic dermatitis and seborrheic dermatitis ${ }^{106}$. Presence of the characteristic lesions, chronic rhinorrhea, recurrent chronic dermatitis, and positive serology for HTLV are the main criteria for diagnosing infective dermatitis, whose treatment consists of administering antibiotics with topical use of corticosteroids, combined or not with antifungals.

Dermatological alterations in ATL vary in presentation (erythroderma, papules, nodules, infiltrating lesions, or erythematous plaques) and depend on the disease stage; nodulations are more frequent in severe forms, especially in the acute, lymphomatous, or cutaneous primary tumoral form ${ }^{107}$. The lesions may evolve indolently and modify with the use of corticosteroids. Histopathological evaluation is essential for specific diagnosis.

\section{UVEITIS IN INDIVIDUALS WITH HTLV-1}

In Japan, uveitis was first reported in $1989^{108}$. Most common in people in age up to 50 years and a little more frequent in women, its exact incidence among HTLV-1 carriers remains uncertain. The disease is manifested by visual disorders, including 'floaters' and blurred or hazy vision, and it is bilateral in almost half of the affected people ${ }^{109}$. Eye signs include iritis, vitreous opacities, retinal vasculitis, and retinal hemorrhages and exudates. There is a good patient response to topical or systemic corticosteroids, although recurrence is common with therapy discontinuation.

\section{COINFECTIONS IN INDIVIDUALS WITH HTLV}

HTLV-infected individuals may present some coinfections, more frequently than the general population, either by sharing infection routes or as a consequence of the immunological alterations induced by the infection itself. Moreover, HTLV can alter the natural course of some coinfections.

In HIV coinfection, for example, the evidence suggests a neutral or even protective role for those coinfected by HTLV-2 $2^{110}$. However, if the coinfection is HIV-1/HTLV-1, the existing data show a higher risk of death, both in adults and in children ${ }^{111}$. The reasons for these findings are not very clear. A hypothesis for the lack of clinical benefit is the delay in introducing the antiretroviral therapy due to the increase in the T-CD4 ${ }^{+}$cells count caused by HTLV-1. Coinfected individuals treated with antiretroviral therapy and with HIV-1 viral suppression present similar survival time to those monoinfected under the same conditions; however, in those with a detectable viral load, the survival of coinfected individuals is significantly lower ${ }^{112}$.

Regarding coinfection with hepatitis $\mathrm{C}$ virus (HCV), existing data are conflicting: while some studies show an increase in HCV viremia and a lower probability of spontaneous clearance of the infection $^{113}$, others suggest a higher chance of elimination of this virus in HIV-1 and HTLV-coinfected individuals, probably due to the immunomodulation caused by HTLV in this group of individuals, resulting from the high production of proinflammatory cytokines ${ }^{114}$. Moreover, studies are suggesting less hepatic damage in triple infected individuals - with HIV, HTLV, and HCV- and a greater chance of spontaneous clearance of $\mathrm{HCV}^{115,116}$.

Individuals with HTLV-1 and Strongyloides stercoralis coinfection suffer a negative impact in the course of both infections, becoming more susceptible to more severe forms of strongyloidiasis, therapeutic resistance, in addition to presenting a higher HTLV-1 proviral load and a higher risk of HTLV-1 vertical transmission $^{117-126}$.

Individuals with HTLV-1 present a higher risk of infection by Mycobacterium tuberculosis ${ }^{127-132}$, but the clinical impact is not clear.

\section{DIAGNOSIS}

In Brazil, routine testing for HTLV-1/2 in blood and organ donors has been performed since 1993 and 2009, respectively ${ }^{42,133}$. In both cases, the infection is a criterion for donor exclusion. Although there is no national policy for HTLV-1/2 antenatal screening in Brazil, the test is done as a routine in some states. The MS/SCTIE Portaria no. 23, of May 31, 2016, included the Western blot (Wb) test and the polymerase chain reaction (PCR) to confirm HTLV-1 infection among patients suspected of ATL assisted by the Brazilian National Health System (SUS) ${ }^{134}$. Figure 3 shows the indications for HTLV-1/2 testing. Laboratory diagnosis must be performed using screening tests, followed by confirmatory tests in a different blood sample when screening test results are positive ${ }^{135-137}$ (Figure 4).

The screening tests are used for detecting antibodies against HTLV-1/2 in plasma or serum. The laboratory techniques for performing these tests include (i) immunoenzymatic reaction, (ii) chemiluminescence, and (iii) particle agglutination ${ }^{136}$. The screening tests present high sensitivity. The negative result excludes infection - unless there is evidence of recent exposure to the virus when it is recommended to repeat the test after 90 days ${ }^{24,25}$. The specificity of screening tests in Brazil varies from 92 to $99.5 \%$. It is highly recommended to perform confirmatory tests to exclude false-positive results in the screening tests ${ }^{136-138}$.

The confirmatory tests identify antibodies against different HTLV-1 and HTLV-2 antigens or amplify and identify proviral genetic material, usually in peripheral blood lymphocytes. Confirmatory and viral typing tests are (i) $\mathrm{Wb}$, (ii) line immunoassay (LIA), and (iii) PCR ${ }^{136}$.

Usually, $\mathrm{Wb}$ and LIA are sufficient for diagnosis; however, in some cases, undetermined or undefined results may occur regarding 
Individuals with clinical manifestations compatible with HTLV-1/2 associated diseases

Blood, organ, or tissue donors

Organ or tissue recipients

Family members and sexual partners of HTLV-1/2 carriers

Individuals with suspicion or with sexually transmitted infections

Individuals with bloodborne infections

Pregnant women

Intravenous drug users

Cases of occupational exposure to blood or biological material, such as an accident with sharp material

Individuals infected with Strongyloides stercoralis

Individuals infected with Mycobacterium tuberculosis

Individuals with leukemia or lymphoma

FIGURE 3: Indications for laboratory testing for the human T-cell lymphotropic virus (HTLV-1/2).

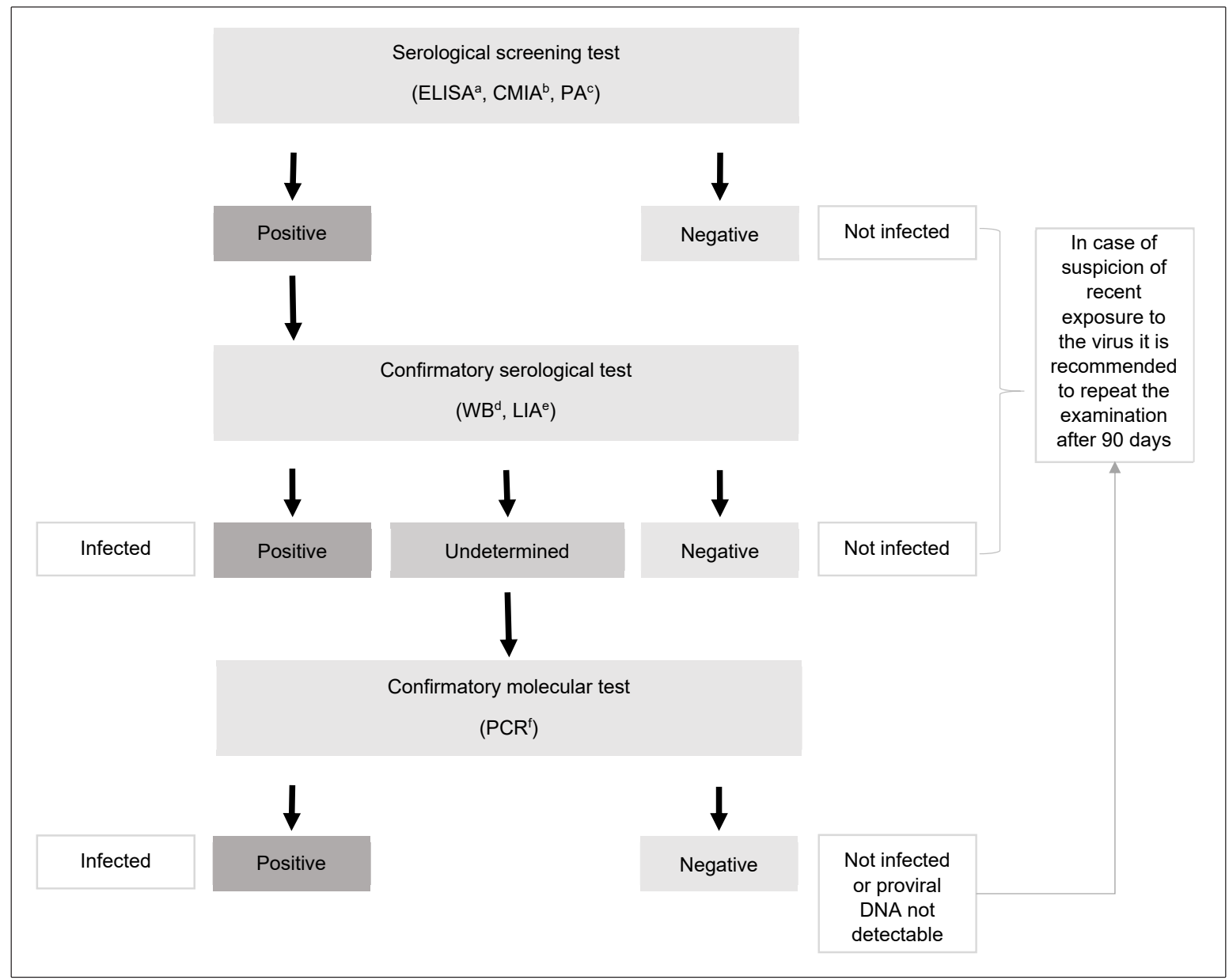

Notes: a) ELISA: immunoenzymatic assay; b) CMIA: chemiluminescence; c) PA: particle agglutination; d) WB: Western blot; e) LIA: line immunoassay; f) PCR: polymerase chain reaction.

FIGURE 4: Recommendations for human T-cell lymphotropic virus (HTLV-1/2) infection laboratory diagnosis. 
the type of HTLV ${ }^{139-149}$, more frequently in individuals infected by HTLV-2 or HIV-1 or both ${ }^{141,150}$. LIA presents greater accuracy in confirming HTLV-1 and HTLV-2 infection when compared to $\mathrm{Wb}^{151,152}$. Indeterminate or untyped results by $\mathrm{Wb}$ or LIA must be submitted to qualitative or quantitative PCR: nested PCR (nPCR) and real-time PCR (RT-PCR) are used. RT-PCR enables not only the quantification of the HTLV-1/2 proviral load but also the stratification of the risk of developing HTLV-1 associated diseases $^{26,93,94,142,153-155}$. The detection of viral RNA is not used in the clinical routine, since viremia is low or absent, even in individuals with $\mathrm{HAM}^{156,157}$.

At the time of this publication, a molecular test for HTLV-1/2 is not commercially available. The tests used are in-house, requiring prior validation ${ }^{155,158-161}$. The absence of commercial tests and standardization of national protocols makes the implementation of molecular testing in the routine and the comparison of results obtained in different laboratories difficult ${ }^{162,163}$. Some individuals infected by HTLV-1/2 may present undetectable proviral load ${ }^{164-166}$. In these cases, it is possible to perform nPCR of higher sensitivity than RT-PCR. Another alternative is to perform a confirmatory serological test (if not yet performed) or to request consecutive samples for follow-up ${ }^{148}$.

There is evidence that the duration of the immunological window period in HTLV-1/2 infection for antibody detection varies from 16 to 39 days after organ transplantation, and for the proviral genetic material, from 16 to 23 days after infection ${ }^{167}$. A study conducted with individuals infected by blood transfusion showed a median seroconversion of 51 days (36 to 72 days) ${ }^{25}$. It is important to emphasize that the methodologies available when this study was developed did not have the same sensitivity as the current diagnostic methods ${ }^{168}$.

\section{TREATMENT}

The therapy for HTLV-1 infection consists of interventions directed to the complications resulting from the disease ${ }^{169,170}$. In 2016, Conitec ${ }^{170}$, and in 2019-2020, the International Retrovirology Association published recommendations for ATL and HAM treatment ${ }^{171,172}$. The use of zidovudine associated with interferonalpha was authorized for the treatment of ATL by the publication of MS/SVS Portaria no. 54 on Jul 18, 2016 $6^{2,170}$. The therapeutic regimens vary according to clinical presentation, progression of symptoms, and local availability of medications.

Infected people must be accompanied in the specialized service to receive psychological support, with particular attention to the early diagnosis of clinical manifestations associated with the infection.

\section{SURVEILLANCE, PREVENTION, AND CONTROL}

Despite being described some decades ago, HTLV infection remains relatively unknown to the general population and health professionals. In the services that assist the infected individuals, the approach should focus not only on the aspects of the risk of becoming sick ${ }^{173}$ but also on preventing the transmission of infection.
After a positive diagnosis for HTLV-1/2 infection, the sexual partners should be invited to undergo serological screening, and those with positive tests must be referred for counseling and appropriate follow-up. Such counseling should include information about the chronicity of the infection and the relevance of long-term clinical follow-up ${ }^{169,174}$. It is important to clarify the initial clinical manifestations and their progression, the transmission mechanisms, and their prevention. The donation of blood, semen, solid organs or tissues and breastfeeding are strongly discouraged.

In HIV and other STI specialized clinical centres, it is important to include HTLV screening in the routine of care. HTLV-infected individual must be oriented about the risk of sexual transmission, serodiscordant sexual partners, and condom use - which may be interrupted during the fertile period when there is a firm decision to become pregnant and following medical counselling and recommendation ${ }^{174}$.

In Brazil, given the scarcity of material available for health professionals and the general population, several initiatives have been developed by academic groups and non-governmental organizations to disseminate information about HTLV-1/2. Among the organizations and initiatives with this purpose, the following should be highlighted: the Research Support Center on Retroviruses (NAP-Retroviruses) of the University of São Paulo; the Hemominas Foundation Journals on HTLV infection; the HTLVida Association; and the Vitamóre Group - Association of HTLV Carriers.

The lack of a national register system impairs the identification of the actual scenario of the infection in the country and, therefore, the implementation of specific public health policies. It is essential to highlight that case notification is one of the pillars of confrontation and research about HTLV-1 in countries like Japan, England, Spain, and Martinique island ${ }^{175-178}$.

\section{SPECIAL POPULATIONS}

\section{Pregnant women}

In Brazil, HTLV-1/2 prevalence in pregnant women can reach $1 \%$ in certain regions of the country (Table 1) ) $^{159,179-196}$. Despite reports about the development of HTLV-associated diseases in pregnancy (HAM, ATL), there is no consistent evidence about the impact on the pregnancy-puerperium cycle ${ }^{23}$. However, childhood infection is associated with an increased risk of developing diseases associated with HTLV-1, especially ATL that has a high lethality ${ }^{23,197,198}$. Therefore, prevention of mother to child transmission is essential to reduce the incidence of diseases associated with the virus ${ }^{23,96,137}$.

Since breastfeeding is the main mother to child transmission route of HTLV-1/2 $135,199-204$ and there is no vaccine against the infection or even any curative treatment, breastfeeding is contraindicated in mothers infected by the virus. For these women, the use of lactation inhibitors is recommended and the provision of infants with milk formula substitutes ${ }^{2}$. Universal antenatal HTLV-1/2 infection screening is not provided by the SUS, but it is recommended to test all pregnant women, followed by counselling for those infected and their relatives, allowing the effective implementation of prevention strategies. 
TABLE 1: Prevalence of HTLV-1/2 infection in pregnant women in different Brazilian states.

\begin{tabular}{|c|c|c|c|}
\hline Region/State & Prevalence (\%) & $\mathbf{n}$ & References $^{a}$ \\
\hline \multicolumn{4}{|l|}{ North } \\
\hline \multirow{2}{*}{ Pará } & 0.6 & 324 & Guerra et al. $2018^{188 ~ b}$ \\
\hline & 0.3 & 13,382 & Sequeira et al. $2012^{192}$ \\
\hline Amazonas & 0 & 674 & Machado Filho et al. $2010^{194}$ \\
\hline \multicolumn{4}{|l|}{ Northeast } \\
\hline \multirow[t]{3}{*}{ Alagoas } & 0.2 & 54,813 & Moura et al. $2015^{179}$ \\
\hline & 0.14 & 692 & Boa-Sorte et al. $2014^{190 c}$ \\
\hline & 1.05 & 2,766 & Mello et al. $2014^{191}$ \\
\hline \multirow[t]{3}{*}{ Bahia } & 0.98 & 408 & Magalhães et al. $2008^{195}$ \\
\hline & 0.84 & 6,754 & Bittencourt et al. $2001^{183}$ \\
\hline & 0.88 & 1,024 & Santos et al. $1995^{185}$ \\
\hline \multirow{2}{*}{ Maranhão } & 0.7 & 713 & Mendes et al. $2020^{186}$ \\
\hline & 0.3 & 2,044 & Guimarães de Souza et al. $2012^{193}$ \\
\hline Ceará & 0.12 & 814 & Broutet et al. $1996^{184}$ \\
\hline \multicolumn{4}{|l|}{ Midwest } \\
\hline \multirow{2}{*}{ Mato Grosso do Sul } & 0.13 & 116,689 & Dal Fabbro et al. $2008^{196}$ \\
\hline & 0.1 & 32,512 & Figueiró Filho et al. $2007^{180}$ \\
\hline Goiás & 0.1 & 15,485 & Oliveira et al. $2006^{181}$ \\
\hline \multicolumn{4}{|l|}{ Southeast } \\
\hline \multirow{2}{*}{ Rio de Janeiro } & 0.74 & 1,628 & Barmpas et al. $2019^{187}$ \\
\hline & 0.66 & 1,204 & Monteiro et al. $2014^{189}$ \\
\hline São Paulo & 0.1 & 913 & Olbrich Neto et al, 2004 182 \\
\hline \multicolumn{4}{|l|}{ South } \\
\hline Paraná & 0.31 & 643 & Medeiros et al. $2018^{159 d}$ \\
\hline
\end{tabular}

a) Only studies with confirmatory tests for HTLV-1/2 infection were included; b) Adolescent pregnant women; c) Study with blood samples on filter paper; d) High-risk pregnant women.

\section{Indigenous peoples}

The vertical and sexual transmission routes are essential for HTLV maintenance in epidemiologically closed or semi-closed communities, as it occurs with HTLV-2c, which is prevalent among indigenous people residing in the Brazilian Amazon and urban areas ${ }^{12,13,205-209}$. It is worth remembering that intrafamiliar infection in the Kayapó communities is important and it is observed the transmission of the virus between two or three generations and in more than $20 \%$ of infected children under nine years old ${ }^{12}$. Vertical transmission maintains the virus in high endemicity since the usual nonbreastfeeding procedures by infected mothers are not followed regularly ${ }^{205}$. The increasing number of reports associating diseases with HTLV-2 $2^{5,43-48}$ infections requires special attention to the indigenous communities located in areas of high virus endemicity in the Brazilian Amazon ${ }^{39}$.

\section{CONCLUSIONS}

Although HTLV infection is neglected, Brazil has produced several initiatives directed towards the prevention of HTLV-1 infection and disease. The complications with relevant clinical consequences, such as HTLV-1 associated myelopathy and T-cell leukemia/lymphoma, can be minimized with access to services offered by the SUS. The low complexity cases can be assisted at the health centers and, when necessary, forwarded to the specialized centers for treatment, rehabilitation, and social support. Despite the severe consequences that the infection can have on people's lives, its control still represents a public health challenge. National epidemiological studies, development and validation of diagnostic tests, and elaboration of clinical protocols with new therapeutic options can define public policies and specific actions towards the approach, prevention, control, and adequate treatment of HTLV-1/2 infection in Brazil.

\section{ACKNOWLEDGMENTS}

The authors are grateful to the technical panel of specialists responsible for elaborating the 2020 PCDT for Comprehensive Care for People with Sexually Transmitted Infections.

\section{AUTHORS' CONTRIBUTIONS}

Rosadas C,Brites C,Arakaki-SanchezD, CassebJ, and IshakR Rontributed with the concept, design, drafting, and critical reviewing of the manuscript. All authors approved the final version, and they are responsible for all aspects of the work, including the assurance of its accuracy, precision, and integrity. 


\section{ORCID}

Carolina Rosadas - 0000-0002-3922-5667

Carlos Brites - 0000-0002-4673-6991

Denise Arakaki-Sanchez - 0000-0001-8026-2876

Jorge Casseb - 0000-0002-4553-2559

Ricardo Ishak - 0000-0002-4741-6201

\section{REFERENCES}

1. Ministério da Saúde (BR). Portaria MS/SCTIE no 42, de 5 de outubro de 2018. Torna pública a decisão de aprovar o Protocolo Clínico e Diretrizes Terapêuticas para Atenção Integral às Pessoas com Infecções Sexualmente Transmissíveis (IST), no âmbito do Sistema Único de Saúde - SUS [Internet]. Diário Oficial da União, Brasília (DF), 2018 out 8 [cited 2020 oct 15];Seção I:88. Available from: https://www.in.gov.br/ materia/-/asset_publisher/Kujrw0TZC2Mb/content/id/44303574/do12018-10-08-portaria-n-42-de-5-de-outubro-de-2018-44303438

2. Ministério da Saúde(BR). Protocolo clínico e diretrizes terapêuticas para atenção integral às pessoas com infeções sexualmente transmissíveis (IST) [Internet]. Brasília: Ministério da Saúde; 2020 [cited 2020 jun 14]. Available from: http://www.aids.gov.br/pt-br/pub/2015/protocoloclinico-e-diretrizes-terapeuticas-para-atencao-integral-pessoas-com$\underline{\text { infeccoes }}$

3. Poiesz BJ, Ruscetti FW, Gazdar AF, Bunn PA, Minna JD, Gallo RC. Detection and isolation of type $\mathrm{C}$ retrovirus particles from fresh and cultured lymphocytes of a patient with cutaneous T-cell lymphoma. Proc Natl Acad Sci U S A [Internet]. 1980 Dec [cited 2020 Oct 15];77(12):74159. Available from: https://doi.org/10.1073/pnas.77.12.7415

4. Poiesz BJ, Ruscetti FW, Reitz MS, Kalyanaraman VS, Gallo RC. Isolation of a new type $\mathrm{C}$ retrovirus (HTLV) in primary uncultured cells of a patient with Sézary T-cell leukaemia. Nature [Internet]. 1981 Nov [cited 2020 Oct 15];294:268-71. Available from: https://doi. org $/ 10.1038 / 294268 \mathrm{a} 0$

5. Kalyanaraman VS, Sarngadharan MG, Robert-Guroff M, Miyoshi I, Golde D, Gallo RC. A new subtype of human T-cell leukemia virus (HTLV-II) associated with a T-cell variant of hairy cell leukemia. Science [Internet]. 1982 Nov [cited 2020 Oct 15];218(4572):571-3. Available from: https://doi.org/10.1126/science.6981847

6. Gallo RC. History of the discoveries of the first human retroviruses: HTLV-1 and HTLV-2. Oncogene [Internet]. 2005 Sep [cited 2020 Oct 15];24(39):5926-30. Available from: https://doi.org/10.1038/ sj.onc. 1208980

7. International Commitee on Taxonomy of Viruses - ICTV. Taxonomy history: primate T-lymphotropic virus 1 [Internet]. [S.1.]: ICTV; 2017 [cited 2020 Oct 15]. Available from: https://talk.ictvonline.org/taxonomy/p/ taxonomy-history?taxnode id=19911434\&src=NCBI\&ictv_id=19911434

8. Miura T, Fukunaga T, Igarashi T, Yamashita M, Ido E, Funahashi S, et al. Phylogenetic subtypes of human T-lymphotropic virus type I and their relations to the anthropological background. Proc Natl Acad Sci U S A [Internet]. 1994 Feb [cited 2020 Oct 15];91(3):1124-7. Available from: https://doi.org/10.1073/pnas.91.3.1124

9. Vidal AU, Gessain A, Yoshida M, Mahieux R, Nishioka K, Tekaia F, et al. Molecular epidemiology of HTLV type I in Japan: evidence for two distinct ancestral lineages with a particular geographical distribution. AIDS Res Hum Retroviruses [Internet]. 1994 Nov [cited 2020 Oct 15];10(11):155766. Available from: https://doi.org/10.1089/aid.1994.10.1557
10. Van Dooren S, Salemi M, Vandamme AM. Dating the origin of the African human T-cell lymphotropic virus type-i (HTLV-I) subtypes. Mol Biol Evol [Internet]. 2001 Apr [cited 2020 Oct 15];18(4):661-71. Available from: https://doi.org/10.1093/oxfordjournals.molbev.a003846

11. Hall WW, Takahashi H, Liu C, Kaplan MH, Ijichi S, Nagashima K, et al. Multiple isolates and characteristics of human T-cell leukemia virus type II. J Virol [Internet]. 1992 Apr [cited 2020 Oct 15];66(4):245663. Available from: https://www.ncbi.nlm.nih.gov/pmc/articles/ PMC289041/

12. Ishak R, Harrington WJ, Azevedo VN, Eiraku N, Ishak MO, Guerreiro $\mathrm{JF}$, et al. Identification of human $\mathrm{T}$ cell lymphotropic virus type IIa infection in the Kayapo, an indigenous population of Brazil. AIDS Res Hum Retroviruses [Internet]. 1995 Jul [cited 2020 Oct 15];11(7):813-21. Available from: https://doi.org/10.1089/aid.1995.11.813

13. Eiraku N, Novoa P, Costa Ferreira M, Monken C, Ishak R, Costa Ferreira $\mathrm{O}$, et al. Identification and characterization of a new and distinct molecular subtype of human T-cell lymphotropic virus type 2. J Virol [Internet]. 1996 Mar [cited 2020 Oct 15];70(3):1481-92. Available from: https://www.ncbi.nlm.nih.gov/pmc/articles/PMC189969/

14. Vandamme AM, Salemi M, Van Brussel M, Liu HF, van Laethem K, van Ranst M, et al. African origin of human T-lymphotropic virus type 2 (HTLV2) supported by a potential new HTLV-2d subtype in Congolese Bambuti Efe Pygmies. J Virol [Internet]. 1998 May [cited 2020 Oct 15];72(5):4327-40. Available from: https:/www.ncbi.nlm.nih.gov/pmc/articles/PMC109663/

15. Wolfe ND, Heneine W, Carr JK, Garcia AD, Shanmugam V, Tamoufe $\mathrm{U}$, et al. Emergence of unique primate T-lymphotropic viruses among central African bushmeat hunters. Proc Natl Acad Sci U S A [Internet]. 2005 May [cited 2020 Oct 15];102(22):7994-9. Available from: https://doi.org/10.1073/pnas.0501734102

16. Perzova R, Benz P, Abbott L, Welch C, Thomas A, Ghoul RW, et al. Short communication: no evidence of HTLV-3 and HTLV-4 infection in New York State subjects at risk for retroviral infection. AIDS Res Hum Retroviruses [Internet]. 2010 Nov [cited 2020 Oct 15];26(11):1229-31. Available from: https://doi.org/10.1089/aid.2010.0079

17. Duong YT, Jia H, Lust JA, Garcia AD, Tiffany AJ, Heneine W, et al. Short communication: Absence of evidence of HTLV-3 and HTLV-4 in patients with large granular lymphocyte (LGL) leukemia. AIDS Res Hum Retroviruses [Internet]. 2008 Dec [cited 2020 Oct 15];24(12):15035. Available from: https://doi.org/10.1089/aid.2008.0128

18. Gessain A, Cassar O. Epidemiological aspects and world distribution of HTLV-1 infection. Front Microbiol [Internet]. 2012 Nov [cited 2020 Oct 15];3:388. Available from: https://dx.doi. org $/ 10.3389 \% 2 \mathrm{Ffmicb} .2012 .00388$

19. Ishak R, Vallinoto ACR, Azevedo VN, Lewis M, Hall WW, Ishak MOG. Molecular evidence of mother-to-child transmission of HTLVIIc in the Kararao Village ( Kayapo ) in the Amazon Region of Brazil. Rev Soc Bras Med Trop [Internet]. 2001 [cited 2020 Oct 15];34(6):51925. Available from: https://doi.org/10.1590/S0037-86822001000600004

20. Moriuchi M, Moriuchi H. Seminal fluid enhances replication of human T-cell leukemia virus type 1: implications for sexual transmission. J Virol [Internet]. 2004 Nov [cited 2020 Oct 15];78(22):12709-11. Available from: https://dx.doi.org/10.1128\%2FJVI.78.22.12709-12711.2004

21. Lairmore MD, Anupam R, Bowden N, Haines R, Haynes RAH, Ratner $\mathrm{L}$, et al. Molecular determinants of human T-lymphotropic virus type 1 transmission and spread. Viruses [Internet]. 2011 Jul [cited 2020 Oct 15];3(7):1131-65. Available from: https://dx.doi.org/10.3390\%2Fv3071131

22. Mendoza C, Roc L, Benito R, Reina G, Ramos JM, Gómez C, et al. HTLV-1 infection in solid organ transplant donors and recipients in Spain. BMC Infect Dis [Internet]. 2019 Aug [cited 2020 Oct 15];19:706. Available from: https://doi.org/10.1186/s12879-019-4346-z 
23. Rosadas C, Taylor GP. Mother-to-child HTLV-1 transmission: unmet research needs. Front Microbiol [Internet]. 2019 May [cited 2020 Oct 15];10:999. Available from: https://doi.org/10.3389/fmicb.2019.00999

24. Cook LBM, Melamed A, Demontis MA, Laydon DJ, Fox JM, Tosswill JHC, et al. Rapid dissemination of human T-lymphotropic virus type 1 during primary infection in transplant recipients. Retrovirology [Internet]. 2016 Jan [cited 2020 Oct 15];13:3. Available from: https://doi. org/10.1186/s12977-015-0236-7

25. Manns A, Wilks RJ, Murphy EL, Haynes G, Barnett M, Hanchard B, et al. A prospective study of transmission by transfusion of HTLV-I and risk factors associated with seroconversion. Int J Cancer [Internet]. 1992 Jul [cited 2020 Oct 15];51(6):886-91. Available from: https://doi. org/10.1002/ijc.2910510609

26. Nagai M, Usuku K, Matsumoto W, Kodama D, Takenouchi N, Moritoyo T, Hashiguchi S, et al. Analysis of HTLV-I proviral load in $202 \mathrm{HAM} /$ TSP patients and 243 asymptomatic HTLV-I carriers: high proviral load strongly predisposes to HAM/TSP. J Neurovirol [Internet]. 1998 Dec [cited 2020 Oct 15];4(6):586-93. Available from: https://doi. $\underline{\text { org } / 10.3109 / 13550289809114225}$

27. Dias-Bastos MR, Oliveira CDL, Carneiro-Proietti ABF. Decline in prevalence and asymmetric distribution of human $\mathrm{T}$ cell lymphotropic virus 1 and 2 in blood donors, State of Minas Gerais, Brazil, 1993 to 2007. Rev Soc Bras Med Trop [Internet]. 2010 Nov-Dec [cited 2020 Oct 15];43(6):615-9. Available from: https://doi.org/10.1590/S0037$\underline{86822010000600002}$

28. Carneiro-Proietti ABF, Sabino EC, Leão S, Salles NA, Loureiro P, Sarr $\mathrm{M}$, et al. Human T-lymphotropic virus type 1 and type 2 seroprevalence, incidence, and residual transfusion risk among blood donors in Brazil during 2007-2009. AIDS Res Hum Retroviruses [Internet]. 2012 Oct [cited 2020 Oct 15];28(10):1265-72. Available from: https://doi. org/10.1089/aid.2011.0143

29. Lairmore MD, Jacobson S, Gracia F, De BK, Castillo L, Larreategui $\mathrm{M}$, et al. Isolation of human T-cell lymphotropic virus type 2 from Guaymi Indians in Panama. Proc Natl Acad Sci U S A [Internet]. 1990 Nov [cited 2020 Oct 15];87(22):8840-4. Available from: https://dx.doi. org/10.1073\%2Fpnas.87.22.8840

30. Nunes D, Boa-Sorte N, Grassi MFR, Taylor GP, Teixeira MG, Barreto ML, et al. HTLV-1 is predominantly sexually transmitted in Salvador, the city with the highest HTLV-1 prevalence in Brazil. PLoS One [Internet]. 2017 Feb [cited 2020 Oct 15];12:e0171303. Available from: https://doi.org/10.1371/journal.pone.0171303

31. Costa CA, Furtado KCYO, Ferreira LSC, Almeida DS, Linhares AC, Ishak R, et al. Familial Transmission of Human T-cell Lymphotrophic Virus: Silent Dissemination of an Emerging but Neglected Infection. PLoS Negl Trop Dis [Internet]. 2013 Jun [cited 2020 Oct 15];7:e2272. Available from: https://doi.org/10.1371/journal.pntd.0002272

32. Satake M, Yamaguchi K, Tadokoro K. Current prevalence of HTLV1 in Japan as determined by screening of blood donors. J Med Virol [Internet]. $2012 \mathrm{Feb}$ [cited 2020 Oct 15];84(2):327-35. Available from: https://doi.org/10.1002/jmv.23181

33. Hananiya HS, Ella EE, Aminu M, Anyanwu NCJ. Prevalence of human T-cell lymphotropic virus and the socio-demographic and risk factors associated with the infection among post-natal clinics women in Zaria, Nigeria. J Immunoassay Immunochem [Internet]. 2019 [cited 2020 Oct 15];40(5):485-94. Available from: https://doi.org/10.1080/15321819.2019 .1636817

34. Braço ILJ, Sá KSG, Waqasi M, Queiroz MAF, Silva ANR, CayresVallinoto IMV, et al. High prevalence of human T-lymphotropic virus 2 (HTLV-2) infection in villages of the Xikrin tribe (Kayapo), Brazilian Amazon region. BMC Infect Dis [Internet]. 2019 May [cited 2020 Oct 15];19(1):459. Available from: https://doi.org/10.1186/s12879-019-4041-0
35. Murphy EL, Figueroa JP, Gibbs WN, Brathwaite A, Holding-Cobham $\mathrm{M}$, Waters D, et al. Sexual transmission of human T-lymphotropic virus type I (HTLV-I). Ann Intern Med [Internet]. 1989 Oct [cited 2020 Oct 15];111(7):555-60. Available from: https://doi.org/10.7326/0003-4819111-7-555

36. La Rosa AM, Zunt JR, Peinado J, Lama JR, Ton TGN, Suarez L, et al. Retroviral infection in Peruvian men who have sex with men. Clin Infect Dis [Internet]. 2009 Jul [cited 2020 Oct 15];49(1):112-7. Available from: https://dx.doi.org/10.1086\%2F599609

37. Zunt JR, La Rosa AM, Peinado J, Lama JR, Suarez L, Pun M, et al. Risk factors for HTLV-II infection in Peruvian men who have sex with men. Am J Trop Med Hyg [Internet]. 2006 May [cited 2020 Oct 15];74(5):9225. Available from: https://www.ncbi.nlm.nih.gov/entrez/eutils/elink.fcgi ?dbfrom $=$ pubmed\&retmode $=$ ref\&cmd $=$ prlinks\&id $=16687704$

38. Galvão-Castro B, Loures L, Rodriques LG, Sereno A, Ferreira Júnior OC, Franco LG, et al. Distribution of human T-lymphotropic virus type I among blood donors: a nationwide Brazilian study. Transfusion [Internet]. 1997 Feb [cited 2020 Oct 15];37(2):242-3. Available from: https://doi.org/10.1046/j.1537-2995.1997.37297203532.x

39. Ishak R, Ishak MOG, Vallinoto ACR. The challenge of describing the epidemiology of HTLV in the Amazon region of Brazil. Retrovirology [Internet]. $2020 \mathrm{Feb}$ [cited 2020 Oct 15];17:4. Available from: https:// dx.doi.org/10.1186\%2Fs12977-020-0512-Z

40. Einsiedel L, Woodman RJ, Flynn M, Wilson K, Cassar O, Gessain A. Human T-lymphotropic virus type 1 infection in an indigenous Australian population: epidemiological insights from a hospital-based cohort study. BMC Public Health [Internet]. 2016 Aug [cited 2020 Oct 15];16:787. Available from: https://doi.org/10.1186/s12889-016$\underline{3366-5}$

41. Paiva AM, Assone T, Haziot MEJ, Smid J, Fonseca LAM, Luiz OC, et al. Risk factors associated with HTLV-1 vertical transmission in Brazil: longer breastfeeding, higher maternal proviral load and previous HTLV1-infected offspring. Sci Rep [Internet]. 2018 [cited 2020 Oct 15];8:7742. Available from: https://doi.org/10.1038/s41598-018-25939-y

42. Brasil. Ministério da Saúde. Portaria GM/MS n. 1376, de 19 de novembro de 1993. Aprova alterações na Portaria no 721/GM, de 09.08.89, que aprova Normas Técnicas para coleta, processamento e transfusão de sangue, componentes e derivados, e dá outras providências [Internet]. Diário Oficial da União, Brasília (DF), 1993 dez 2 [cited 2020 oct 15];Seção I:18405. Available from: http://redsang.ial.sp.gov.br/site/ docs leis/ps/ps29.pdf

43. Hjelle B, Appenzeller O, Mills R, Appenzeller O, Jahnke R, Alexander $\mathrm{S}$, et al. Chronic neurodegenerative disease associated with HTLV-II infection. Lancet [Internet].1992 Mar [cited 2020 Oct 15];339(8794):6456. Available from: https://doi.org/10.1016/0140-6736(92)90797-7

44. Zucker-Franklin D, Hooper WC, Evatt BL. Human lymphotropic retroviruses associated with mycosis fungoides: evidence that human T-cell lymphotropic virus type II (HTLV-II) as well as HTLV-I may play a role in the disease. Blood [Internet]. 1992 Sep [cited 2020 Oct 15];80(6):1537-45. Available from: https://pubmed.ncbi.nlm.nih. gov/1520878/

45. Maytal J, Horowitz S, Lipper S, Poiesz B, Wang CY, Siegal FP. Progressive nemaline rod myopathy in a woman coinfected with HIV-1 and HTLV-2. Mt Sinai J Med. 1993 May;60(3):242-6.

46. Peters AA, Oger JJ, Coulthart MB, Waters DJ, Cummings HJ, Dekaban GA. An apparent case of human T-cell lymphotropic virus type II (HTLV-II)-associated neurological disease: a clinical, molecular, and phylogenetic characterization. J Clin Virol [Internet]. 1999 Sep [cited 2020 Oct 15];14(1):37-50. Available from: https://doi.org/10.1016/S13866532(99)00041-4 
47. Araujo A, Hall WW. Human T-Lymphotropic virus type ii and neurological disease. Ann Neurol [Internet]. 2004 Jul [cited 2020 Oct 15];56(1):10-9. Available from: https://doi.org/10.1002/ana.20126

48. Rosadas C, Vicente ACP, Zanella L, Cabral-Castro MJ, Peralta JM, Puccioni-Sohler M. Human T-lymphotropic virus type 2 subtype $b$ in a patient with chronic neurological disorder. J Neurovirol [Internet]. 2014 Dec [cited 2020 Oct 15];20(6):636-9. Available from: https://doi. org/10.1007/s13365-014-0280-4

49. Black FL. Tracing prehistoric migrations by the viruses they carry: human T-cell lymphotropic viruses as markers of ethnic relationships. Hum Biol. 1997 Aug;69(4):467-82.

50. Ishak R, Machado LFA, Cayres-Vallinoto I, Guimarães Ishak MO, Vallinoto ACR. Infectious agents as markers of human migration toward the Amazon Region of Brazil. Front Microbiol [Internet]. 2017 Aug [cited 2020 Oct 15];8:1663. Available from: https://dx.doi. org $/ 10.3389 \% 2 \mathrm{Ffmicb} .2017 .01663$

51. Katsuya H, Ishitsuka K, Utsunomiya A, Hanada S, Eto T, Moriuchi Y, et al. Treatment and survival among 1594 patients with ATL. Blood [Internet]. 2015 Dec [cited 2020 Oct 15];126(24):2570-7. Available from: https://doi.org/10.1182/blood-2015-03-632489

52. Taniguchi H, Imaizumi Y, Takasaki Y, Nakashima J, Kato T, Itonaga $\mathrm{H}$, et al. Clinical features at transformation in adult T-cell leukemialymphoma with smoldering and chronic types. Int J Hematol [Internet]. 2019 Apr [cited 2020 Oct 15];109(4):402-8. Available from: https://doi. org/10.1007/s12185-019-02602-4

53. Rodgers-Johnson P, Gajdusek DC, Morgan OS, Zaninovic V, Sarin PS, Graham DS. HTLV-I and HTLV-III antibodies and tropical spastic paraparesis. Lancet (London, England) [Internet]. 1985 Oct [cited 2020 Oct 15];2(8466):1247-8. Available from: https://doi.org/10.1016/s0140$\underline{6736(85) 90778-0}$

54. Osame M, Usuku K, Izumo S, Ijichi N, Amitani H, Igata A, et al. HTLV-I associated myelopathy, a new clinical entity. Lancet [Internet]. 1986 May [cited 2020 Oct 15];1(8488):1031-2. Available from: https:// doi.org/10.1016/s0140-6736(86)91298-5

55. Araujo AQ-C. Update on neurological manifestations of HTLV-1 infection. Curr Infect Dis Rep [Internet]. 2015 Feb [cited 2020 Oct 15];17(2):459. Available from: https://doi.org/10.1007/s11908-014-0459-0

56. Bangham CRM, Araujo A, Yamano Y, Taylor GP. HTLV-1-associated myelopathy/tropical spastic paraparesis. Nat Rev Dis Primers [Internet]. 2015 Jun [cited 2020 Oct 15];1:15012. Available from: https://doi. org/10.1038/nrdp.2015.12

57. Nozuma S, Jacobson S. Neuroimmunology of human T-Lymphotropic virus type 1-associated myelopathy/tropical spastic paraparesis. Front Microbiol [Internet]. 2019 Apr [cited 2020 Oct 15];10:885. Available from: https://dx.doi.org/10.3389\%2Ffmicb.2019.00885

58. Chew R, Henderson T, Aujla J, Whist E, Einsiedel L. Turning a blind eye: HTLV-1-associated uveitis in Indigenous adults from Central Australia. Int Ophthalmol [Internet]. 2018 Oct [cited 2020 Oct 15];38(5):2159-62. Available from: https://doi.org/10.1007/s10792-017-0659-3

59. Nakao K, Abematsu N, Sakamoto T. Systemic diseases in patients with HTLV-1-associated uveitis. Br J Ophthalmol [Internet]. 2018 Mar [cited 2020 Oct 15];102(3):373-6. Available from: https://doi.org/10.1136/ bjophthalmol-2017-310658

60. Kamoi K, Okayama A, Izumo S, Hamaguchi I, Uchimaru K, Tojo A, et al. Tackling HTLV-1 infection in ophthalmology: a nationwide survey of ophthalmic care in an endemic country, Japan. Br J Ophthalmol [Internet]. 2020 Mar [cited 2020 Oct 15]. Available from: https://doi. org/10.1136/bjophthalmol-2019-315675
61. Schierhout G, McGregor S, Gessain A, Einsiedel L, Martinello M, Kaldor J. Association between HTLV-1 infection and adverse health outcomes: a systematic review and meta-analysis of epidemiological studies. Lancet Infect Dis [Internet]. 2019 Jan [cited 2020 Oct 15];20(1):133-43. Available from: https://doi.org/10.1016/s1473-3099(19)30402-5

62. Bimbi C, Brzezinski P, Sokolowska-Wojdylo M. Crusted (Norwegian) scabies as a strong marker of adult T-cell leukemia/lymphoma in HTLV1 infection. Clin Case Reports [Internet]. 2019 Mar [cited 2020 Oct 15];7(3):474-6. Available from: https://dx.doi.org/10.1002\%2Fccr3.1983

63. Magno Falcão LF, Falcão ASC, Medeiros Sousa RC, Vieira WB, Oliveira RTM, Normando VMF, et al. CT Chest and pulmonary functional changes in patients with HTLV-associated myelopathy in the Eastern Brazilian Amazon. PLoS One [Internet]. 2017 Nov [cited 2020 Oct 15];12(11):e0186055. Available from: https://doi.org/10.1371/ journal.pone.0186055

64. Dias ARN, Falcão LFM, Falcão ASC, Normando VMF, Quaresma JAS. Human T lymphotropic virus and pulmonary diseases. Front Microbiol [Internet]. 2018 Aug [cited 2020 Oct 15];9:1879. Available from: https:// dx.doi.org/10.3389\%2Ffmicb.2018.01879

65. Kako S, Joshita S, Matsuo A, Kawaguchi K, Umemura T, Tanaka E. A case of adult T-Cell leukemia/lymphoma complicated with bilateral chylothorax. Case Rep Oncol Med [Internet]. 2019 Feb [cited 2020 Oct 15];2019:8357893. Available from: https://doi.org/10.1155/2019/8357893

66. Nishioka K, Maruyama I, Sato K, Kitajima I, Nakajima Y, Osame M. Chronic inflammatory arthropathy associated with HTLV-I. Lancet [Internet]. 1989 Feb [cited 2020 Oct 15];1(8635):441. Available from: https://doi.org/10.1016/s0140-6736(89)90038-x

67. Sato K, Maruyama I, Maruyama Y, Kitajima I, Nakajima Y, Higaki M, et al. Arthritis in patients infected with human $\mathrm{T}$ lymphotropic virus type I. Clinical and immunopathologic features. Arthritis Rheum [Internet]. 1991 Jun [cited 2020 Oct 15];34(6):714-21. Available from: https://doi.org/10.1002/art.1780340612

68. Dennis G, Chitkara P. A case of human T lymphotropic virus type I-associated synovial swelling. Nat Clin Pract Rheumatol [Internet]. 2007 Nov [cited 2020 Oct 15];3:675-80. Available from: https://doi. org/10.1038/ncprheum0648

69. Kawai H, Inui T, Kashiwagi S, Tsuchihashi T, Masuda K, Kondo A, et al. HTLV-I infection in patients with autoimmune thyroiditis (Hashimoto's thyroiditis). J Med Virol [Internet]. 1992 Oct [cited 2020 Oct 15];38(2):13841. Available from: https://doi.org/10.1002/jmv.1890380212

70. Matsuda T, Tomita M, Uchihara J-N, Okudaira T, Ohshiro K, Tomoyose $\mathrm{T}$, et al. Human $\mathrm{T}$ cell leukemia virus type I-infected patients with Hashimoto's thyroiditis and Graves' disease. J Clin Endocrinol Metab [Internet]. 2005 Oct [cited 2020 Oct 15];90(10):5704-10. Available from: https://doi.org/10.1210/jc.2005-0679

71. Abolbashari S, Darroudi S, Tayefi M, Khashyarmaneh Z, Zamani P, Haghighi HM, et al. Association between serum zinc and copper levels and antioxidant defense in subjects infected with human T-lymphotropic virus type 1. J Blood Med [Internet]. 2018 Dec [cited 2020 Oct 15];10:2935. Available from: https://doi.org/10.2147/jbm.s184913

72. Mohammadi FS, Mosavat A, Shabestari M, Shabestari M, Ghezeldasht SA, Shabestari M, et al. HTLV-1-host interactions facilitate the manifestations of cardiovascular disease. Microb Pathog [Internet]. 2019 Sep [cited 2020 Oct 15];134:103578. Available from: https://doi. org/10.1016/j.micpath.2019.103578

73. Oliveira TSS, Andrade RCP, Santos DN, Orrico KF, Abraão Neto J, Oliveira CJV, et al. Prevalence of Bowel Symptoms in Patients Infected with Human T-Lymphotropic type 1 Virus. Rev Soc Bras Med Trop [Internet]. 2019 Nov [cited 2020 Oct 15];52:e20180486. Available from: http://dx.doi.org/10.1590/0037-8682-0486-2018 
74. Silva MT, Coutinho F, Leite AC, Harab RC, Araújo A, Andrada-Serpa MJ. Isolated bladder dysfunction in human $\mathrm{T}$ lymphotropic virus type 1 infection. Clin Infect Dis [Internet]. 2009 Feb [cited 2020 Oct 15];48(3):e34-6. Available from: https://doi.org/10.1086/595855

75. Nayar S, Pawar B, Einsiedel L, Fernandes D, George P, Thomas S, et al. Isolated neurogenic bladder associated with human T-Lymphotropic virus type 1 infection in a renal transplant patient from central Australia: a case report. Transplant Proc [Internet]. 2018 Dec [cited 2020 Oct 15];50(10):3940-2. Available from: https://doi.org/10.1016/j. transproceed.2018.08.031

76. Tanajura D, Castro N, Oliveira P, Abraão Neto, Muniz A, Carvalho $\mathrm{NB}$, et al. Neurological manifestations in human T-cell lymphotropic virus type 1 (HTLV-1)-infected individuals without HTLV-1-associated myelopathy/tropical spastic paraparesis: a longitudinal cohort study. Clin Infect Dis [Internet]. 2015 Jul [cited 2020 Oct 15];61(1):49-56. Available from: https://doi.org/10.1093/cid/civ229

77. Haziot ME, Gascon MR, Assone T, Fonseca LAM, Luiz OC, Smid J, et al. Detection of clinical and neurological signs in apparently asymptomatic HTLV-1 infected carriers: Association with high proviral load. PLoS Negl Trop Dis [Internet]. 2019 May [cited 2020 Oct 15];13:e0006967. Available from: https://doi.org/10.1371/journal.pntd.0006967

78. Yamano Y, Nagai M, Brennan M, Mora CA, Soldan SS, Tomaru U, et al. Correlation of human T-cell lymphotropic virus type 1 (HTLV1) mRNA with proviral DNA load, virus-specific CD8+ T cells, and disease severity in HTLV-1-associated myelopathy (HAM/TSP). Blood [Internet]. 2002 Jan [cited 202 Oct 15];99(1):88-94. Available from: https://doi.org/10.1182/blood.v99.1.88

79. Montanheiro PA, Oliveira ACP, Posada-Vergara MP, Milagres AC, Tauil C, et al. Human T-cell lymphotropic virus type I (HTLV-I) proviral DNA viral load among asymptomatic patients and patients with HTLV-I-associated myelopathy/tropical spastic paraparesis. Brazilian J Med Biol Res [Internet]. 2005 Nov [cited 2020 Oct 15];38(11):1643-7. Available from: http://dx.doi.org/10.1590/S0100-879X2005001100011

80. Champs APS, Passos VMA, Barreto SM, Vaz LS, Ribas JGR. HTLV-1 associated myelopathy: clinical and epidemiological profile in a 10-year case series study. Rev Soc Bras Med Trop [Internet]. 2010 [cited 2020 Oct 15];43(6):668-72. Available from: http://dx.doi.org/10.1590/S0037$\underline{86822010000600013}$

81. Okajima R, Casseb J, Sanches JA. Co-presentation of human T-cell lymphotropic virus type 1 (HTLV-1)-associated myelopathy/tropical spastic paraparesis and adult-onset infective dermatitis associated with HTLV-1 infection. Int J Dermatol [Internet]. 2013 Jan [cited 2020 Oct 15];52(1):63-8. Available from: https://doi.org/10.1111/j.1365-4632.2012.05606.x

82. Okajima R, Oliveira ACP, Smid J, Casseb J, Sanches JA. High prevalence of skin disorders among HTLV-1 infected individuals independent of clinical status. PLoS Negl Trop Dis [Internet]. 2013 Nov [cited 2020 Oct 15];7(11):e2546. Available from: https://dx.doi.org/10.1371\%2Fjournal. pntd. 0002546

83. Araujo AQC, Wedemann D. HTLV-1 Associated neurological complex. What is hidden below the water? AIDS Rev [Internet]. 2019 [cited 2020 Oct 15];21(4):211-7. Available from: https://doi.org/10.24875/aidsrev.19000108

84. Matsuzaki T, Nakagawa M, Nagai M, Usuku K, Arimura K, Kubota $\mathrm{H}$, et al. HTLV-I proviral load correlates with progression of motor disability in HAM/TSP: analysis of $239 \mathrm{HAM} / \mathrm{TSP}$ patients including 64 patients followed up for 10 years. J Neurovirol [Internet]. 2001 Jun [cited 2020 Oct 15];7(3):228-34. Available from: https://doi. org/10.1080/13550280152403272

85. Rosadas C, Puccioni-Sohler M. Relevance of retrovirus quantification in cerebrospinal fluid for neurologic diagnosis. J Biomed Sci [Internet]. 2015 Aug [cited 2020 Oct 15];22(1):66. Available from: https://doi. org/10.1186/s12929-015-0170-y
86. Hayashi D, Kubota R, Takenouchi N, Nakamura T, Umehara F, Arimura $\mathrm{K}$, et al. Accumulation of human T-lymphotropic virus type I (HTLVI)-infected cells in the cerebrospinal fluid during the exacerbation of HTLV-I-associated myelopathy. J Neurovirol [Internet]. 2008 Oct [cited 2020 Oct 15];14(5):459-63. Available from: https://doi. org/10.1080/13550280802178538

87. Lezin A, Olindo S, Oliere S, Varrin-Doyer M, Martin R, Cabre P, et al. Human T lymphotropic virus type I (HTLV-I) proviral load in cerebrospinal fluid: a new criterion for the diagnosis of HTLVI-associated myelopathy/tropical spastic paraparesis? J Infect Dis [Internet]. 2005 Jun [cited 2020 Oct 15];191(11):1830-4. Available from: https://doi.org/10.1086/429962

88. Starling ALB, Coelho-dos-Reis JGA, Peruhype-Magalhães V, PascoalXavier MA, Gonçalves DU, Béia SR, et al. Immunological signature of the different clinical stages of the HTLV-1 infection: establishing serum biomarkers for HTLV-1-associated disease morbidity. Biomarkers [Internet]. 2015 [cited 2020 Oct 15];20(6-7):502-12. Available from: https://doi.org/10.3109/1354750x.2015.1094141

89. Yamauchi J, Araya N, Yagishita N, Sato T, Yamano Y. An update on human T-cell leukemia virus type I (HTLV-1)-associated myelopathy/ tropical spastic paraparesis (HAM/TSP) focusing on clinical and laboratory biomarkers. Pharmacol Ther [Internet]. 2020 Aug [cited 2020 Oct 15];107669. Available from: https://doi.org/10.1016/j. pharmthera.2020.107669

90. Apoliano CF, Assone T, Maciel da Silva BC, Corral MA, Oliveira ACP, Fonseca LAM, et al. Interferon- $\gamma$ secretion enzyme-linked immunospot assay determined among human $\mathrm{T}$ cell lymphotropic virus type 1-infected subjects: a potential laboratory marker for early HTLV-1associated myelopathy/tropical spastic paraparesis diagnosis. AIDS Res Hum Retroviruses [Internet]. 2020 Jan [cited 2020 Oct 15];36(1):6-7. Available from: https://doi.org/10.1089/aid.2018.0290

91. Tajima K, Cartier L. Epidemiological features of HTLV-I and adult T cell leukemia. Intervirology [Internet]. 1995 [cited 2020 Oct 15];38(34):238-46. Available from: https://doi.org/10.1159/000150438

92. Kondo T, Kono H, Miyamoto N, Yoshida R, Toki H, Matsumoto I, et al. Age- and sex-specific cumulative rate and risk of ATLL for HTLV-I carriers. Int J cancer [Internet]. 1989 Jun [cited 2020 Oct 15];43(6):10614. Available from: https://doi.org/10.1002/ijc.2910430618

93. Nosaka K, Iwanaga M, Imaizumi Y, Ishitsuka K, Ishizawa K, Ishida Y, et al. Epidemiological and clinical features of adult T-cell leukemialymphoma in Japan, 2010-2011: a nationwide survey. Cancer Sci [Internet]. 2017 Dec [cited 2020 Oct 15];108(12):2478-86. Available from: https://doi.org/10.1111/cas.13398

94. Iwanaga M, Watanabe T, Utsunomiya A, Okayama A, Uchimaru K, Koh KR, et al. Human T-cell leukemia virus type I (HTLV-1) proviral load and disease progression in asymptomatic HTLV-1 carriers: a nationwide prospective study in Japan. Blood [Internet]. 2010 Aug [cited 2020 Oct 15];116(8):1211-9. Available from: https://doi.org/10.1182/ blood-2009-12-257410

95. Phillips AA, Shapira I, Willim RD, Sanmugarajah J, Solomon WB, Horwitz SM, et al. A critical analysis of prognostic factors in North American patients with human T-cell lymphotropic virus type-1-associated adult T-cell leukemia/lymphoma: a multicenter clinicopathologic experience and new prognostic score. Cancer [Internet]. $2010 \mathrm{Jul}$ [cited 2020 Oct 15];116(14):3438-46. Available from: https://doi.org/10.1002/cncr.25147

96. Rosadas C, Puccioni-Sohler M, Oliveira ACP, Casseb J, Sousa M, Taylor GP. Adult T-cell leukaemia/lymphoma in Brazil: a rare disease or rarely diagnosed? Br J Haematol [Internet]. 2020 Feb [cited 2020 Oct 15];188(4):e46-9. Available from: https://doi.org/10.1111/bjh.16318 
97. van Tienen $\mathrm{C}$, Visser O, Lugtenburg $\mathrm{P}$, Taylor G, Cook L. Overrepresentation of patients from HTLV-1 endemic countries among $\mathrm{T}$ cell Non-Hodgkin lymphomas in the Netherlands: an indication of under-diagnosis of Adult T cell leukaemia/lymphoma. Br J Haematol [Internet]. 2018 Feb [cited 2020 Oct 15];184(4):688-9. Available from: https://doi.org/10.1111/bjh.15160

98. Lymphoma Study Group. Major prognostic factors of patients with adult T-cell leukemia-lymphoma: a cooperative study. Leuk Res [Internet]. 1991 [cited 2020 Oct 15];15(2-3):81-90. Available from: https://doi. org/10.1016/0145-2126(91)90087-A

99. Tsukasaki K, Hermine O, Bazarbachi A, Ratner L, Ramos JC, Harrington Jr W, et al. Definition, prognostic factors, treatment, and response criteria of adult T-cell leukemia-lymphoma: a proposal from an international consensus meeting. J Clin Oncol [Internet]. 2009 Jan [cited 2020 Oct 15];27(3):453-9. Available from: https://doi.org/10.1200/ je. 2008.18.2428

100. Shimoyama M. Diagnostic criteria and classification of clinical subtypes of adult T-cell leukaemia-lymphoma. A report from the Lymphoma Study Group (1984-87). Br J Haematol [Internet]. 1991 Nov [cited 2020 Oct 15];79(3):42837. Available from: https://doi.org/10.1111/j.1365-2141.1991.tb08051.x

101. Yared JA, Kimball AS. Optimizing management of patients with adult $\mathrm{T}$ cell leukemia-lymphoma. Cancers (Basel) [Internet]. 2015 Dec [cited 2020 Oct 15];7(4):2318-29. Available from: https://dx.doi. org $/ 10.3390 \% 2 \mathrm{Fcancers} 7040893$

102.Brites C, Weyll M, Pedroso C, Badaró R. Severe and Norwegian scabies are strongly associated with retroviral (HIV-1/HTLV-1) infection in Bahia, Brazil. AIDS [Internet]. 2002 Jun [cited 2020 Oct 15];16(9):1292-3. Available from: https://doi.org/10.1097/00002030-200206140-00015

103.Dantas L, Netto E, Glesby MJ, Carvalho EM, Machado P. Dermatological manifestations of individuals infected with human $\mathrm{T}$ cell lymphotropic virus type I (HTLV-I). Int J Dermatol [Internet]. 2014 Sep [cited 2020 Oct 15];53(9):1098-102. Available from: https://doi.org/10.1111/ijd.12170

104.LaGrenade L, Hanchard B, Fletcher V, Cranston B, Blattner W. Infective dermatitis of Jamaican children: a marker for HTLV-I infection. Lancet (London, England) [Internet]. 1990 Dec [cited 2020 Oct 15];336(8727):13457. Available from: https://doi.org/10.1016/0140-6736(90)92896-p

105. Bittencourt AL, Primo J, Oliveira MFP. Manifestations of the human T-cell lymphotropic virus type I infection in childhood and adolescence. J Pediatr (Rio J) [Internet]. 2006 [cited 2020 Oct 15];82(6):411-20. Available from: http://dx.doi.org/10.2223/JPED.1573

106. Oliveira MFSP, Fatal PL, Primo JRL, Silva JLS, Batista ES, Ferré L, et al. Infective dermatitis associated with human T-cell lymphotropic virus type 1: evaluation of 42 cases observed in Bahia, Brazil. Clin Infect Dis [Internet]. 2012 Jun [cited 2020 oct 15];54(12):1714-9. Available from: https://doi.org/10.1093/cid/cis273

107.Bittencourt AL, Oliveira MFP. Cutaneous manifestations associated with HTLV-1 infection. Int J Dermatol [Internet]. 2010 Oct [cited 2020 Oct 15];49(10):1099-110. Available from: https://doi.org/10.1111/j.13654632.2010.04568.x

108. Ohba N, Matsumoto M, Sameshima M, Kabayama Y, Nakao K, Unoki K, et al. Ocular manifestations in patients infected with human T-lymphotropic virus type I. Jpn J Ophthalmol. 1989;33(1):1-12.

109.Mochizuki M, Tajima K, Watanabe T, Yamaguchi K. Human T lymphotropic virus type 1 uveitis. Br J Ophthalmol [Internet]. 1994 Feb [cited 2020 Oct 15];78(2):149-54. Available from: https://dx.doi. org $/ 10.1136 \% 2 \mathrm{Fbjo} .78 .2 .149$

110.Brites C, Sampalo J, Oliveira A. HIV/human T-cell lymphotropic virus coinfection revisited: impact on AIDS progression. AIDS Rev [Internet]. 2009 Jan-Mar [cited 2020 Oct 15];11(1):8-16. Available from: https://pubmed.ncbi.nlm.nih.gov/19290030/
111. Pedroso C, Netto EM, Weyll N, Brites C. Coinfection by HIV-1 and human lymphotropic virus type 1 in Brazilian children is strongly associated with a shorter survival time. J Acquir Immune Defic Syndr [Internet]. 2011 Aug [cited 2020 Oct 15];57 Suppl 3:S208-11. Available from: https://doi.org/10.1097/qai.0b013e31821e9baf

112. Brites C, Miranda F, Luz E, Netto EM. Early and successful combination antiretroviral therapy normalizes survival time in patients coinfected with human immunodeficiency virus and human T-cell lymphotrophic virus type 1. Clin Infect Dis [Internet]. 2020 Jun [cited 2020 Oct 15];71(1):196200. Available from: https://doi.org/10.1093/cid/ciz756

113. Boschi-Pinto C, Stuver S, Okayama A, Trichopoulod D, Orav EJ, Tsubouchi $\mathrm{H}$, et al. A follow-up study of morbidity and mortality associated with hepatitis $\mathrm{C}$ virus infection and its interaction with human T lymphotropic virus type I in Miyazaki, Japan. J Infect Dis [Internet]. 2000 Jan [cited 2020 Oct 15];181(1):35-41. Available from: https://doi.org/10.1086/315177

114. Brites C, Abrahão M, Bozza P, Netto EM, Lyra A, Bahia F. Infection by HTLV-1 Is associated with high levels of proinflammatory cytokines in HIV-HCV-coinfected patients. J Acquir Immune Defic Syndr [Internet]. 2018 Feb [cited 2020 Oct 15];77(2):230-4. Available from: https://doi. org/10.1097/qai.0000000000001576

115.Bahia F, Novais V, Evans J, Marchand CL, Netto E, Page K, et al. The impact of human T-cell lymphotropic virus infection on clinical and immunologic outcomes in patients coinfected with HIV and hepatitis C virus. J Acquir Immune Defic Syndr [Internet]. 2011 Aug [cited 2020 Oct 15];57(3):S202-7. Available from: https://dx.doi.org/10.1097\%2FQA I.0b013e31821e9ale

116. Marchand CL, Bahia F, Page K, Brites C. Hepatitis C virus infection and spontaneous clearance in HTLV-1 and HIV coinfected patients in Salvador, Bahia, Brazil. Braz J Infect Dis [Internet]. 2015 [cited 2020 Oct 15];19(5):486-91. Available from: http://dx.doi.org/10.1016/j. bjid.2015.06.007

117. Gillet NA, Cook L, Laydon DJ, Hlela C, Verdonck K, Alvarez $\mathrm{C}$, et al. Strongyloidiasis and infective dermatitis alter human $\mathrm{T}$ lymphotropic virus-1 clonality in vivo. PLoS Pathog [Internet]. 2013 Apr [cited 2020 Oct 15];9(4):e1003263. Available from: https://dx.doi. org/10.1371\%2Fjournal.ppat.1003263

118. Nakada K, Yamaguchi K, Furugen S, Nakasone K, Oshiro Y, Kohakura $\mathrm{M}$, et al. Monoclonal integration of HTLV-I proviral DNA in patients with strongyloidiasis. Int J Cancer [Internet]. 1987 Aug [cited 2020 Oct 15];40(2):145-8. Available from: https://doi.org/10.1002/ijc.2910400203

119. Newton RC, Limpuangthip P, Greenberg S, Gam A, Neva FA. Strongyloides stercoralis hyperinfection in a carrier of HTLV-I virus with evidence of selective immunosuppression. Am J Med [Internet]. 1992 Feb [cited 2020 Oct 15];92(2):202-8. Available from: https://doi. org/10.1016/0002-9343(92)90113-p

120.Terashima A, Alvarez H, Tello R, Infante R, Freedman DO, Gotuzzo E. Treatment failure in intestinal strongyloidiasis: an indicator of HTLV-I infection. Int J Infect Dis [Internet]. 2002 Mar [cited 2020 Oct 15];6(1):2830. Available from: https://doi.org/10.1016/s1201-9712(02)90132-3

121.Gotuzzo E, Moody J, Verdonck K, Cabada MM, González E, van Dooren $\mathrm{S}$, et al. Frequent HTLV-1 infection in the offspring of Peruvian women with HTLV-1 - associated myelopathy / tropical spastic paraparesis or strongyloidiasis. Rev Panam Salud Publica [Internet]. 2007 Oct [cited 2020 Oct 15];22(4):223-30. Available from: https://doi.org/10.1590/ $\underline{\mathrm{s} 1020-49892007000900001}$

122.Porto MAF, Muniz A, Oliveira Júnior J, Carvalho EM. Implicações clinicas e imunológicas da associação entre o HTLV-1 e a estrongiloidíase. Rev Soc Bras Med Trop [Internet]. 2002 [cited 2020 oct 15];35(6):641-9. Available from: https://doi.org/10.1590/S0037-86822002000600016 
123.Sato Y, Shiroma Y. Concurrent infections with Strongyloides and T-cell leukemia virus and their possible effect on immune responses of host. Clin Immunol Immunopathol [Internet]. 1989 Aug [cited 2020 Oct 15];52(2):214-24. Available from: https://doi.org/10.1016/0090$\underline{1229(89) 90173-6}$

124.Salles F, Bacellar A, Amorim M, Orge G, Sundberg M, Lima M, et al. Treatment of strongyloidiasis in HTLV-1 and Strongyloides stercoralis coinfected patients is associated with increased tnf $\alpha$ and decreased soluble IL2 receptor levels. Trans R Soc Trop Med Hyg [Internet]. 2013 Aug [cited 2020 Oct 15];107(8):526-9. Available from: https://doi.org/10.1093/trstmh/ $\underline{\operatorname{trt} 052}$

125.Gabet A-S, Mortreux F, Talarmin A, Plumelle Y, Leclercq I, Leroy A, et al. High circulating proviral load with oligoclonal expansion of HTLV1 bearing T cells in HTLV-1 carriers with strongyloidiasis. Oncogene [Internet]. 2000 Oct [cited 2020 Oct 15];19(43):4954-60. Available from: https://doi.org/10.1038/sj.onc.1203870

126.Plumelle Y, Gonin C, Edouard A, Bucher BJ, Thomas L, Brebion A, et al. Effect of Strongyloides stercoralis infection and eosinophilia on age at onset and prognosis of adult T-cell leukemia. Am J Clin Pathol [Internet]. 1997 Jan [cited 2020 Oct 15];107(1):81-7. Available from: https://doi.org/10.1093/ ajcp/107.1.81

127. Schierhout G, McGregor S, Gessain A, Einsiedel L, Martinello M, Kaldor J. Association between HTLV-1 infection and adverse health outcomes: a systematic review and meta-analysis of epidemiological studies. Lancet Infect Dis [Internet]. 2019 Apr [cited 2020 Oct 15];20(4):407-8. Available from: https://doi.org/10.1016/S1473-3099(20)30133-X

128.Marinho J, Galvao-Castro B, Rodrigues LC, Barreto ML. Increased risk of tuberculosis with human T-lymphotropic virus-1 infection a casecontrol study. J Acquir Immune Defic Syndr [Internet]. 2005 [cited 2020 Oct 15];40(5):625-8. Available from: https://www.arca.fiocruz.br/handle/ icict $/ 8131$

129.Norrgren HR, Bamba S, Larsen O, Silva Z, Aaby P, Koivula T, et al. Increased prevalence of HTLV-1 in patients with pulmonary tuberculosis coinfected with HIV, but not in HIV-negative patients with tuberculosis. J Acquir Immune Defic Syndr [Internet]. 2008 Aug [cited 2020 Oct 15];48(5):607-10. Available from: https://doi.org/10.1097/ qai.0b013e $31817 \mathrm{efb} 83$

130. Moreira ED, Ribeiro TT, Swanson P, Sampoio Filho C, Melo A, Brites C, et al. Seroepidemiology of human T-cell lymphotropic virus type I/II in northeastern Brazil. J Acquir Immune Defic Syndr. 1993 Aug;6(8):959-63.

131. Hanada S, Uematsu T, Iwahashi M, Nomura K, Utsunomiya A, Kodama $\mathrm{M}$, et al. The prevalence of human T-cell leukemia virus type I infection in patients with hematologic and nonhematologic diseases in an adult T-cell leukemia-endemic area of Japan. Cancer [Internet]. 1989 Sep [cited 2020 Oct 15];64(6):1290-5. Available from: https://doi.org/10.1002/10970142(19890915)64:6\%3C1290::aid-cncr2820640620\%3E3.0.co;2-z

132.Verdonck K, Gonzalez E, Schrooten W, Vanham G, Gotuzzo E. HTLV1 infection is associated with a history of active tuberculosis among family members of HTLV-1-infected patients in Peru. Epidemiol Infect [Internet]. 2008 Aug [cited 2020 Oct 15];136(8):1076-83. Available from: https://dx.doi.org/10.1017\%2FS0950268807009521

133. Brasil. Ministério da Saúde. Portaria n. 2.600, de 21 de outubro de 2009. Aprova o Regulamento Técnico do Sistema Nacional de Transplantes [Internet]. Diário Oficial da União, Brasília (DF), 2009 out 30 [cited 2020 jun 14];Seção I:77. Available from: http://bvsms.saude.gov.br/bvs/ saudelegis/gm/2009/prt2600_21_10_2009.html

134.Brasil. Ministério da Saúde. Portaria n. 23, de 31 de maio de 2016. Torna pública a decisão de incorporar os procedimentos laboratoriais por técnicas de Western Blot e PCR em tempo real no diagnóstico de leucemia/linfoma de células T do adulto associado ao HTLV-1, no âmbito do Sistema Único de Saúde - SUS [Internet]. Diário Oficial da União,
Brasília (DF), 2016 jun 6 [cited 2020 jun 14];Seção I:45. Available from: http://bvsms.saude.gov.br/bvs/saudelegis/sctie/2016/prt0023 $31 \quad 05 \quad 2016$. html\%09\%09\%09\%09\%09\%09

135.Itabashi K, Miyazawa T, Sekizawa A, Tokita A, Saito S, Moriuchi $\mathrm{H}$, et al. A nationwide antenatal human T-cell leukemia virus type1 antibody screening in Japan. Front Microbiol [Internet]. 2020 Apr [cited 2020 Oct 15];11:595. Available from: https://dx.doi. org $/ 10.3389 \% 2$ Ffmicb. 2020.00595

136.Cassar O, Gessain A. Serological and molecular methods to study epidemiological aspects of human T-cell lymphotropic virus type 1 infection. Methods Mol Biol [Internet]. 2017 [cited 2020 Oct 15];1582:3-24. Available from: https://doi.org/10.1007/978-1-4939-6872-5_1

137.Puccioni-Sohler M, Grassi MFR, Galvão-Castro B, Caterino A, Proietti ABFC, Vicente ACP, et al. Increasing awareness of human T-lymphotropic virus type-1 infection: a serious, invisible, and neglected health problem in Brazil. Rev Soc Bras Med Trop [Internet]. 2019 Oct [cited 2020 Oct 15];52:e20190343. Available from: http://dx.doi.org/10.1590/0037-8682-0343-2019

138.Silva Brito V, Santos FLN, Gonçalves NLS, Araújo THA, Nascimento DSV, Pereira FM, et al. Performance of commercially available serological screening tests for human T-cell lymphotropic virus infection in Brazil. J Clin Microbiol [Internet]. 2018 Nov [cited 2020 Oct 15];56(12):e00961. Available from: https://doi.org/10.1128/jem.00961-18

139.Cánepa C, Salido J, Ruggieri M, Fraile S, Pataccini G, Berinii C, et al. Low Proviral load is associated with indeterminate western blot patterns in human T-cell lymphotropic virus type 1 infected individuals: could punctual mutations be related? Viruses [Internet]. 2015 Nov [cited 2020 Oct 15];7(11):5643-58. Available from: https://dx.doi. org $/ 10.3390 \% 2 \mathrm{Fv} 7112897$

140.Tebourski F, Slim A, Elgaaied A. The significance of combining World Health Organization and Center for Disease Control criteria to resolve indeterminate human immunodeficiency virus type-1 Western blot results. Diagn Microbiol Infect Dis [Internet]. 2004 Jan [cited 2020 Oct 15];48(1):59-61. Available from: https://doi.org/10.1016/j. diagmicrobio.2003.08.004

141. Ishak R, Vallinoto ACR, Azevedo VN, Vicente ACP, Hall WW, Ishak MOG. Molecular evidence for infection by HTLV-2 among individuals with negative serological screening tests for HTLV antibodies. Epidemiol Infect [Internet]. 2007 May [cited 2020 Oct 15];135(4):604-9. Available from: https://doi.org/10.1017/s0950268806006984

142.Kuramitsu M, Sekizuka T, Yamochi T, Firouzi S, Sato T, Umeki K, et al. Proviral features of human $\mathrm{T}$ cell leukemia virus type 1 in carriers with indeterminate western blot analysis results. J Clin Microbiol [Internet]. 2017 Sep [cited 2020 Oct 15];55(9):2838-49. Available from: https://doi. org/10.1128/jcm.00659-17

143. Araujo AC, Casseb JS, Neitzert E, Souza ML, Mammano F, Mistro AD, et al. HTLV-I and HTLV-II infections among HIV-1 seropositive patients in Sao Paulo, Brazil. Eur J Epidemiol [Internet]. 1994 Apr [cited 2020 Oct 15];10(2):165-71. Available from: https://doi.org/10.1007/ bf01730366

144.Campos KR, Gonçalves MG, Costa NA, Caterino-de-Araujo A. Comparative performances of serologic and molecular assays for detecting human T lymphotropic virus type 1 and type 2 (HTLV-1 and HTLV-2) in patients infected with human immunodeficiency virus type 1 (HIV-1). Brazilian J Infect Dis [Internet]. 2017 [cited 2020 Oct 15];21(3):297-305. Available from: http://dx.doi.org/10.1016/j.bjid.2017.02.005

145.Jacob F, Santos-Fortuna E, Azevedo RS, Caterino-de-Araujo A. Serological patterns and temporal trends of HTLV-1/2 infection in highrisk populations attending Public Health Units in São Paulo, Brazil. J Clin Virol [Internet]. 2008 Jun [cited 2020 Oct 15];42(2):149-55. Available from: https://doi.org/10.1016/j.jcv.2008.01.017 
146.Morimoto HK, Morimoto AA, Reiche EMV, Ueda LT, Matsuo T, Reiche FV, et al. Difficulties in the diagnosis of HTLV-2 infection in HIV/ AIDS patients from Brazil: comparative performances of serologic and molecular assays, and detection of HTLV-2b subtype. Rev Inst Med Trop São Paulo [Internet]. 2007 Jul-Aug [cited 2020 Oct 15];49(4):225-30. Available from: http://dx.doi.org/10.1590/S0036-46652007000400006

147. Mangano AM, Remesar M, del Pozo A, Sen L. Human T lymphotropic virus types I and II proviral sequences in Argentinian blood donors with indeterminate Western blot patterns. J Med Virol [Internet]. 2004 Oct [cited Oct 15];74(2):323-7. Available from: https://doi.org/10.1002/jmv.20172

148.Martins ML, Santos ACS, Namen-Lopes MS, Barbosa-Stancioli EF, Utsch DG, Carneiro-Proietti ABF. Long-term serological follow-up of blood donors with an HTLV-Indeterminate Western Blot: Antibody Profile of Seroconverters and Individuals With False Reactions. J Med Virol [Internet]. 2010 Oct [cited 2020 Oct 15];82(10):1746-53. Available from: https://doi.org/10.1002/jmv.21881

149. Abrams A, Akahata Y, Jacobson S. The prevalence and significance of HTLV-I/II seroindeterminate western blot patterns. Viruses [Internet]. 2011 Aug [cited 2020 Oct 15];3(8):1320-31. Available from: https://dx.doi.org/10.3390\%2Fv3081320

150.Campos KR, Santos FLN, Silva Brito V, Gonçalves NLS, Araújo THA, Galvão-Castro B, et al. Line immunoassay for confirmation and discrimination of human T-cell lymphotropic virus infections in inconclusive western blot serum samples from Brazil. J Clin Microbiol [Internet]. 2019 Dec [cited 2020 Oct 15];58(1):e01384-19. Available from: https://doi.org/10.1128/jcm.01384-19

151.Umeki K, Umekita K, Hashikura Y, Yamamoto I, Kubo K, Nagatomo $\mathrm{Y}$, et al. Evaluation of line immunoassay to detect HTLV-1 infection in an endemic area, southwestern Japan; comparison with polymerase chain reaction and western blot. Clin Lab [Internet]. 2017 Feb [cited 2020 Oct 15];63(2):227-33. Available from: https://doi.org/10.7754/clin. lab.2016.160501

152.Okuma K, Kuramitsu M, Niwa T, Taniguchi T, Masaki Y, Ueda G, et al. Establishment of a novel diagnostic test algorithm for human T-cell leukemia virus type 1 infection with line immunoassay replacement of western blotting: a collaborative study for performance evaluation of diagnostic assays in Japan. Retrovirology [Internet]. 2020 Aug [cited 2020 Oct 15];17(1):26. Available from: https://doi.org/10.1186/s12977020-00534-0

153.Primo J, Siqueira I, Nascimento MCF, Oliveira MF, Farre L, Carvalho EM, et al. High HTLV-1 proviral load, a marker for HTLV-1 associated myelopathy/tropical spastic paraparesis, is also detected in patients with infective dermatitis associated with HTLV-1. Brazilian J Med Biol Res [Internet]. $2009 \mathrm{Jul}$ [cited 2020 Oct 15];42(8):761-4. Available from: https://doi.org/10.1590/S0100-879X2009005000008

154.Hisada M, Okayama A, Shioiri S, Spiegelman DL, Stuver SO, Mueller NE. Risk factors for adult T-cell leukemia among carriers of human T-lymphotropic virus type I. Blood. 1998 Nov;92(10):3557-61.

155.Rosadas C, Cabral-Castro MJ, Vicente ACP, Peralta JM, PuccioniSohler M. Validation of a quantitative real-time PCR assay for HTLV-1 proviral load in peripheral blood mononuclear cells. J Virol Methods [Internet]. 2013 Nov [cited 2020 Oct 15];193(2):536-41. Available from: https://doi.org/10.1016/j.jviromet.2013.07.040

156.Cabral F, Arruda LB, Araújo ML, Montanheiro P, Smid J, Oliveira ACP, et al. Detection of human T-cell lymphotropic virus type 1 in plasma samples. Virus Res [Internet]. 2012 Jan [cited 2020 Oct 15];163(1):87-90. Available from: https://doi.org/10.1016/j.virusres.2011.08.014

157.Demontis MA, Sadiq MT, Golz S, Taylor GP. HTLV-1 viral RNA is detected rarely in plasma of HTLV-1 infected subjects. J Med Virol [Internet]. 2015 Dec [cited 2020 Oct 15];87(12):2130-4. Available from: https://doi.org/10.1002/jmv.24264
158.Tamegão-lopes BP, Rezende PR, Cunha LM. Carga proviral do HTLV-1 e HTLV-2: um método simples através da PCR quantitativa em tempo real. Rev Soc Bras Med Trop [Internet]. 2006 nov-dez [cited 2020 oct 15];39(6):548-52. Available from: https://doi.org/10.1590/S0037$\underline{86822006000600007}$

159. Medeiros ACM, Vidal LRR, Von Linsingen R, Ferin AN, Strapasson TB, Almeida SM, et al. Confirmatory molecular method for HTLV-1/2 infection in high-risk pregnant women. J Med Virol [Internet]. 2018 May [cited 2020 Oct 15];90(5):998-1001. Available from: https://doi. org/10.1002/jmv.25014

160.Kamihira S, Yamano Y, Iwanaga M, Sasaki D, Satake M, Okayama A, et al. Intra- and inter-laboratory variability in human T-cell leukemia virus type-1 proviral load quantification using real-time polymerase chain reaction assays: a multi-center study. Cancer Sci [Internet]. 2010 Nov [cited 2020 Oct 15];101(11):2361-7. Available from: https://doi.org/10.1111/ j.1349-7006.2010.01720.x

161. Hayden RT, Gu Z, Ingersoll J, Abdul-Ali D, Pounds S, Caliendo AM, et al. Comparison of droplet digital PCR to real-time PCR for quantitative detection of cytomegalovirus. J Clin Microbiol [Internet]. $2013 \mathrm{Feb}$ [cited 2020 Oct 15];51(2):540-6. Available from: https://doi.org/10.1128/ jem.02620-12

162.Grassi MFR, Olavarria VN, Kruschewsky RA, Yamano Y, Jacobson S, Taylor GP, et al. Utility of HTLV proviral load quantification in diagnosis of HTLV-1-associated myelopathy requires international standardization. J Clin Virol [Internet]. 2013 Nov [cited 2020 Oct 15];58(3):584-6. Available from: https://doi.org/10.1016/j.jcv.2013.09.003

163.Kuramitsu M, Okuma K, Yamochi T, Sato T, Sasaki D, Hasegawa H, et al. Standardization of quantitative PCR for human T-cell leukemia virus type 1 in Japan: a collaborative study. J Clin Microbiol [Internet]. 2015 Nov [cited 2020 Oct 15];53(11):3485-91. Available from: https://doi.org/10.1128/jcm.01628-15

164.Lee T-H, Chafets DM, Busch MP, Murphy EL. Quantitation of HTLV-I and II proviral load using real-time quantitative PCR with SYBR Green chemistry. J Clin Virol [Internet]. 2004 Dec [cited 2020 Oct 15];31(4):27582. Available from: https://doi.org/10.1016/i.jcv.2004.05.016

165.Rosadas C, Tosswill JH, Tedder R, Taylor GP. Pregnancy does not adversely impact diagnostic tests for HTLV-1/2 infection. PLoS Negl Trop Dis [Internet]. 2019 Sep [cited 2020 Oct 15];13(9):e0007736. Available from: https://dx.doi.org/10.1371\%2Fjournal.pntd.0007736

166.Montanheiro P, Olah I, Fukumori LMI, Smid J, Oliveira ACP, Kankaki LIB, et al. Low DNA HTLV-2 proviral load among women in São Paulo City. Virus Res [Internet]. 2008 Jul [cited 2020 Oct 15];135(1):22-5. Available from: https://doi.org/10.1016/j.virusres.2008.01.015

167. Cook LBM, Melamed A, Demontis MA, Laydon DJ, Fox JM, Tosswill JHC, et al. Rapid dissemination of human T-lymphotropic virus type 1 during primary infection in transplant recipients. Retrovirology [Internet]. 2016 Jan [cited 2020 Oct 15];13:3. Available from: https://doi. org/10.1186/s12977-015-0236-7

168.Murphy EL. Infection with human T-lymphotropic virus types-1 and -2 (HTLV-1 and -2): implications for blood transfusion safety. Transfus Clin Biol [Internet]. 2016 Feb [cited 2020 Oct 15];23(1):13-9. Available from: https://doi.org/10.1016/j.tracli.2015.12.001

169.Ministério da Saúde (BR). Secretaria de Vigilância em Saúde. Guia de manejo clínico da infecção pelo HTLV [Internet]. Brasilia: Ministério da Saúde; 2013 [cited 2019 feb 4]. Available from: http://www.sierj.org. br/artigos/htlv manual final_pdf 25082.pdf

170. Ministério da Saúde (BR). Protocolo de uso zidovudina para tratamento do adulto com leucemia/linfoma associado ao Vírus HTLV-1 [Internet]. Brasília: Ministério da Saúde; 2016 [cited 2020 oct 15]. Available from: http://www.aids.gov.br/pt-br/pub/2016/protocolo-de-uso-da-zidovudinapara-tratamento-do-adulto-com-leucemialinfoma-associado-ao 
171.Cook LB, Fuji S, Hermine O, Bazarbachi A, Ramos JC, Ratner L, et al. Revised adult T-cell leukemia-lymphoma international consensus meeting report. J Clin Oncol [Internet]. 2019 Mar [cited 2020 Oct 15];37(8):677-87. Available from: https://doi.org/10.1200/jco.18.00501

172.Araujo A, Bangham CRM, Casseb J, Gotuzzo E, Jacobson S, Martin F, et al. Management of HAM/TSP. Neurol Clin Pract [Internet]. 2020 Mar [cited 2020 Oct 15]. Available from: https://doi.org/10.1212/ CPJ.0000000000000832

173.Zihlmann KF, Alvarenga AT, Casseb J. Living invisible: HTLV-1Infected persons and the lack of care in public health. PLoS Negl Trop Dis [Internet]. 2012 [cited 2020 Oct 15];6(6):e1705. Available from: https://doi.org/10.1371/journal.pntd.0001705

174.4Centers for Disease Control and Prevention - CDC. Recommendations for counseling persons infected with human T-lymphotrophic virus, types I and II. MMWR [Internet]. 1993 Jun [cited 2020 Oct 15];42(RR9):1-13. Available from: https://www.cdc.gov/mmwr/preview/ mmwrhtml/00021234.htm

175. Coler-Reilly ALG, Yagishita N, Suzuki H, Sato T, Araya N, Inoue E, et al. Nation-wide epidemiological study of Japanese patients with rare viral myelopathy using novel registration system (HAM-net). Orphanet J Rare Dis [Internet]. 2016 May [cited 2020 Oct 15];11(1):69. Available from: https://doi.org/10.1186/s13023-016-0451-x

176. Olindo S, Jeannin S, Saint-Vil M, Signate A, Edjmonana-Kaptue M, Joux J, Merle H, et al. Temporal trends in human T-lymphotropic virus 1 (HTLV-1) associated myelopathy/tropical spastic paraparesis (HAM/ TSP) incidence in Martinique over 25 years (1986-2010). PLoS Negl Trop Dis [Internet]. 2018 Mar [cited 2020 Oct 15];12(3):e0006304. Available from: https://doi.org/10.1371/journal.pntd.0006304

177. Brant LJ, Cawley C, Davison KL, Taylor GP, the HTLV National Register Steering C. Recruiting individuals into the HTLV cohort study in the United Kingdom: clinical findings and challenges in the first six years, 2003 to 2009. Euro Surveill [Internet]. 2011 Nov [cited 2020 Oct 15];16(46):20017. Available from: https://doi.org/10.2807/ ese.16.46.20017-en

178. Mendoza C, Pirón M, Gonzalez R, Jiménez A, Caballero E, Roc L, et al. Clinical presentation of individuals with human T-cell leukemia virus type-1 infection in Spain. Open Forum Infect Dis [Internet]. 2019 Jan [cited 2020 Oct 15];6(2):ofz036. Available from: https://doi.org/10.1093/ ofid/ofz036

179. Moura AA, Mello MJG, Correia JB. Prevalence of syphilis, human immunodeficiency virus, hepatitis B virus, and human T-lymphotropic virus infections and coinfections during prenatal screening in an urban Northeastern Brazilian population. Int J Infect Dis [Internet]. 2015 Oct [cited 2020 Oct 15];39: 10-5. Available from: https://doi.org/10.1016/j. ijid.2015.07.022

180.Figueiró-Filho EA, Senefonte FRA, Lopes AHA, Morais OO, Souza Júnior VG, Maia TL, et al. Freqüência das infecções pelo HIV-1, rubéola, sífilis, toxoplasmose, citomegalovírus, herpes simples, hepatite B, hepatite C, doença de Chagas e HTLV I/II em gestantes, do Estado de Mato Grosso do Sul. Rev Soc Bras Med Trop [Internet]. 2007 mar-abr [cited 2020 oct 15];40(2):181-7. Available from: https://doi.org/10.1590/ $\underline{\mathrm{S} 0037-86822007000200007}$

181. Oliveira SR, Avelino MM. Soroprevalência do vírus linfotrópico-T humano tipo I entre gestantes em Goiânia, GO, Brasil. Rev Bras Ginecol Obstet [Internet]. 2006 [cited 2020 oct 15];28(8):467-72. Available from: https://doi.org/10.1590/S0100-72032006000800005

182. Olbrich Neto J, Meira DA. Soroprevalence of HTLV-I/II, HIV, syphilis and toxoplasmosis among pregnant women seen at Botucatu - São Paulo - Brazil: risk factors for HTLV-I/II infection. Rev Soc Bras Med Trop [Internet]. 2004 [cited 2020 Oct 15];37(1):28-32. Available from: https:// doi.org/10.1590/S0037-86822004000100008
183.Bittencourt AL, Dourado I, Filho PB, Santos M, Valadão E, Alcantara LC, et al. Human T-cell lymphotropic virus type 1 infection among pregnant women in northeastern Brazil. J Acquir Immune Defic Syndr [Internet]. 2001 Mar [cited 2020 Oct 15];26(5):490-4. Available from: https://doi.org/10.1097/00126334-200104150-00016

184.Broutet N, Queiroz Sousa A, Basilio FP, Sa HL, Simon F, Dabis F. Prevalence of HIV-1, HIV-2 and HTLV antibody, in Fortaleza, Ceara, Brazil, 1993-1994. Int J STD AIDS [Internet]. 1996 Aug-Sep [cited 2020 Oct 15];7(5):365-9. Available from: https://doi.org/10.1258/0956462961918103

185.Santos JI, Lopes MA, Deliège-Vasconcelos E, Couto-Fernandez JC, Patel BN, Barreto ML, et al. Seroprevalence of HIV, HTLV-I/II and other perinatally-transmitted pathogens in Salvador, Bahia. Rev Inst Med Trop São Paulo [Internet]. 1995 Jul-Aug [cited 2020 Oct 15];37(4):3438. Available from: https://doi.org/10.1590/S0036-46651995000400010

186. Mendes FCM, Lima JRO, Melo BO, Pinto CMFS, Maia HS, Ferro TAF, et al. Molecular detection of human T cell lymphotropic virus type 1 in pregnant women from Maranhão state, Brazil. Braz J Microbiol [Internet]. 2020 Jun [cited 2020 Oct 15];51(2):637-45. Available from: https://doi. org/10.1007/s42770-020-00233-0

187.Sodré Barmpas DB, Monteiro DLM, Taquette SR, Rodrigues NCP, Trajano AJB, Cunha JC, et al. Pregnancy outcomes and mother-to-child transmission rate in HTLV-1/2 infected women attending two public hospitals in the metropolitan area of Rio de Janeiro. PLoS Negl Trop Dis [Internet]. 2019 Jun [cited 2020 Oct 15];13(6):e0007404. Available from: https://doi.org/10.1371/journal.pntd.0007404

188. Guerra AB, Siravenha LQ, Laurentino RV, Feitosa RNM, Azecedo VN, Vallinoto ACR, et al. Seroprevalence of HIV, HTLV, CMV, HBV and rubella virus infections in pregnant adolescents who received care in the city of Belém, Pará, Northern Brazil. BMC Pregnancy Childbirth [Internet]. 2018 May [cited 2020 Oct 15];18(1):169. Available from: https://doi.org/10.1186/s12884-018-1753-x

189. Monteiro DLM, Taquette SR, Sodré Barmpas DB, Rodrigues NCP, Teixeira SAM, Villela LHC, et al. Prevalence of HTLV-1/2 in pregnant women living in the metropolitan area of Rio de Janeiro. PLoS Negl Trop Dis [Internet]. 2014 Sep [cited 2020 Oct 15];8:e3146. Available from: https://doi.org/10.1371/journal.pntd.0003146

190. Boa-Sorte N, Purificação A, Amorim T, Assunção L, Reis A, Galvão-Castro B. Dried blood spot testing for the antenatal screening of HTLV, HIV, syphilis, toxoplasmosis and hepatitis B and C: prevalence, accuracy and operational aspects. Brazilian J Infect Dis [Internet]. 2014 Nov-Dec [cited 2020 Oct 15];18(6):618-24. Available from: https://doi.org/10.1016/j.bjid.2014.05.009

191.Mello MAG, Conceição AF, Sousa SMB, Alcântara LC, Marin LJ, Raiol MRS, et al. HTLV-1 in pregnant women from the Southern Bahia, Brazil: a neglected condition despite the high prevalence. Virol J [Internet]. 2014 Feb [cited 2020 Oct 15];11:28. Available from: https://doi.org/10.1186/1743-422X-11-28

192.Sequeira CG, Tamegão-Lopes BP, Santos EJM, Ventura AMR, MoraesPinto MI, Succi RCM. Estudo descritivo da infecção pelo HTLV em uma população de gestantes do Estado do Pará, norte do Brasil. Rev Soc Bras Med Trop [Internet]. 2012 [cited 2020 oct 15];45(4):453-6. Available from: https://doi.org/10.1590/S0037-86822012005000007

193.Souza VG, Martins ML, Carneiro-Proietti ABF, Januário JN, Ladeira RVP, Silva CMS, et al. High prevalence of HTLV-1 and 2 viruses in pregnant women in São Luis, state of Maranhão, Brazil. Rev Soc Bras Med Trop [Internet]. 2012 Mar-Apr [cited 2020 Oct 15];45(2):159-62. Available from: https://doi.org/10.1590/S0037-86822012000200004

194. Machado Filho AC, Sardinha JFJ, Ponte RL, Costa EP, da Silva SS, Martinez-Espinosa FE. Prevalence of infection for HIV, HTLV, HBV and of syphilis and chlamydia in pregnant women in a tertiary health unit in the western Brazilian Amazon region. Rev Bras Ginecol Obstet [Internet]. 2010 Apr [cited 2020 Oct 15];32(4):176-83. Available from: https://doi. org/10.1590/S0100-72032010000400005 
195.Magalhães T, Mota-Miranda AC, Alcantara LCJ, Olavarria V, GalvãoCastro B, Rios-Grassi MF. Phylogenetic and molecular analysis of HTLV1 isolates from a medium sized town in Northern of Brazil: Tracing a common origin of the virus from the most endemic city in the country. J Med Virol [Internet]. 2008 Nov [cited 2020 Oct 15];80(11):2040-5. Available from: https://doi.org/10.1002/jmv.21278

196.Dal Fabbro MMFJ, Cunha RV, Bóia MN, Portela P, Botelho CA, Freitas GMB, et al. Infecção pelo HTLV 1/2: atuação no pré-natal como estratégia de controle da doença no Estado de Mato Grosso do Sul. Rev Soc Bras Med Trop [Internet]. 2008 Mar-Apr [cited 2020 Oct 15];41(2):148-51. Available from: https://doi.org/10.1590/S0037-86822008000200003

197.The T and B-cell malignancy study group. The third nation-wide study on adult T-cell leukemia/lymphoma (ATL) in Japan: characteristic patterns of HLA antigen and HTLV-I infection in ATL patients and their relatives. The T- and B-cell Malignancy Study Group. Int J Cancer [Internet]. 1988 Apr [cited 2020 Oct 15];41(4):505-12. Available from: https://doi.org/10.1002/ijc.2910410406

198. Bartholomew C, Jack N, Edwards J, Charles W, Corbin D, Cleghorn FR, et al. HTLV-I serostatus of mothers of patients with adult T-cell leukemia and HTLV-I-associated myelopathy/tropical spastic paraparesis. J Hum Virol. 1998 May-Jun;1(4):302-5.

199.Hino S. Establishment of the milk-borne transmission as a key factor for the peculiar endemicity of human T-lymphotropic virus type 1 (HTLV1): the ATL Prevention Program Nagasaki. Proc Jpn Acad Ser B Phys Biol Sci [Internet]. 2011 [cited 2020 Oct 15];87(4):152-66. Available from: https://doi.org/10.2183/pjab.87.152

200.Ureta-Vidal A, Angelin-Duclos C, Tortevoye P, Murphy E, Lepere JF, Buigues RP, et al. Mother-to-child transmission of human T-cell-leukemia/ lymphoma virus type I: Implication of high antiviral antibody titer and high proviral load in carrier mothers. Int J Cancer [Internet]. 1999 Sep [cited 2020 Oct 15];82(6):832-6. Available from: https://doi.org/10.1002/(sici)10970215(19990909)82:6\%3C832::aid-ijc11\%3E3.0.co;2-p

201.Oki T, Yoshinaga M, Otsuka H, Miyata K, Sonoda S, Nagata Y. A seroepidemiological study on mother-to-child transmission of HTLV-I in southern Kyushu, Japan. Asia-Oceania J Obstet Gynaecol [Internet]. 1992 Dec [cited 2020 Oct 15];18(4):371-7. Available from: https://doi. org/10.1111/j.1447-0756.1992.tb00333.x
202.Takahashi K, Takezaki T, Oki T, Kawakami K, Yashiki S, Fujiyoshi T, et al. Inhibitory effect of maternal antibody on mother-to-child transmission of human T-lymphotropic virus type I. Int J Cancer [Internet]. $1991 \mathrm{Nov}$ [cited 2020 Oct 15];49(5):673-7. Available from: https://doi.org/10.1002/ ijc. 2910490508

203.Ando Y, Matsumoto Y, Nakano S, Saito K, Kakimoto K, Tanigawa T, et al. Long-term follow-up study of HTLV-I infection in bottle-fed children born to seropositive mothers. J Infect [Internet]. 2003 Jan [cited 2020 Oct 15];46(1):9-11. Available from: https://doi.org/10.1053/jinf.2002.1081

204.Nishijima T, Shimada S, Noda H, Miyake K. Towards the elimination of HTLV-1 infection in Japan. Lancet Infect Dis [Internet]. 2019 Jan [cited 2020 Oct 15];19(1):15-6. Available from: https://doi.org/10.1016/S14733099(18)30735-7

205.Ishak R, Vallinoto AC, Azevedo VN, Lewis M, Hall WW, Guimarães Ishak MO. Molecular evidence of mother-to-child transmission of HTLV-IIc in the Kararao Village (Kayapo) in the Amazon region of Brazil. Rev Soc Bras Med Trop [Internet]. 2001 Nov-Dec [cited 2020 Oct 5];34(6):519-25. Available from: http://dx.doi.org/10.1590/S0037-86822001000600004

206.Silva EA, Otsuki K, Leite ACB, Alamy AH, Sa D, Vicente ACP. HTLVII Infection associated with a chronic neurodegenerative disease: clinical and molecular analysis. J Med Virol [Internet]. 2002 Feb [cited 2020 Oct 15];66(2):253-7. Available from: https://doi.org/10.1002/jmv.2138

207.Catalan-Soares B, Barbosa-Stancioli EF, Alcantara LCJ, et al. HTLV-2 Horizontal and vertical transmission in a family from a Brazilian urban area: seroepidemiological, clinical and molecular study. AIDS Res Hum Retroviruses [Internet]. 2005 Jun [cited 2020 Oct 15];21(6):521-6. Available from: https://doi.org/10.1089/aid.2005.21.521

208.Renner JDP, Laurino JP, Menna-Barreto M, Schmitt VM. Molecular evidence of HTLV-II subtype B among an urban population living in South Brazil. AIDS Res Hum Retroviruses [Internet]. 2006 Apr [cited 2020 Oct 15];22(4):301-6. Available from: https://doi.org/10.1089/aid.2006.22.301

209.Ishak R, Ishak MO, Azevedo VN, Santos DEM, Vallinoto ACR, Saraiva JCP, et al. Detection of HTLV-IIa blood donors in an urban area of the Amazon Region of Brazil (Belém, PA). Rev Soc Bras Med Trop [Internet]. 1998 Mar-Apr [cited 2020 Oct 15];31(2):193-7. Available from: http://dx.doi. org/10.1590/S0037-86821998000200005 